\title{
Hadith Daif dan Palsu dalam Pengurusan Jenazah: Kajian Terhadap Sumber dan Rujukan Masyarakat Islam di Mukim Kutan, Tumpat, Kelantan
}

\author{
Weak and Fabricated Hadith in Funeral Rituals: A Study of Muslim \\ Community Sources and References in Kutan Area, Tumpat, Kelantan
}

\author{
Nur Farha Muhammad Faleh Lai \\ Department of al-Quran and al-Hadith, Academy of Islamic Studies, \\ University of Malaya, 50603 Kuala Lumpur, Malaysia. farhafalehlai@ siswa.um.edu.my
}

Faisal Ahmad Shah

Department of al-Quran and al-Hadith, Academy of Islamic Studies, University of Malaya, 50603 Kuala Lumpur, Malaysia. faisalas@um.edu.my

DOI: https://doi.org/10.22452/usuluddin.vol48no2.2

\begin{abstract}
There are a few practices in Muslims funeral rituals today are stemming from tradition that influenced by the customs and culture of community. There are also rituals that have been practiced through this generation based on weak and fabricated hadiths. Therefore, this quantitative study which involves 361 respondents is to identify the source of funeral rituals for Muslim community in Mukim Kutan, Tumpat Kelantan. Several weak and fabricated hadiths in funeral rituals theme have been selected to see the relevance with community practice. As a result, the sources used by the Muslim community in funeral rituals are from Quran and sunnah, Shāfi'iyyah's view, weak, too weak and fabricated hadiths, also based on customary heritage. However, it is undeniable the practices that consistent to the teaching of Quran and sunnah still dominate in funeral rituals but there are also practices that contradict to sunnah and Shāfi'iyyah's view.
\end{abstract}

Keywords: hadith, funeral, ritual, community

\begin{abstract}
Abstrak
Terdapat beberapa amalan dalam pengurusan jenazah yang dipraktikkan umat Islam pada hari ini bersumberkan daripada warisan yang dipengaruhi oleh adat dan budaya masyarakat sesuatu tempat. Terdapat juga ritual yang diamalkan sejak turun-temurun ini bersandarkan kepada hadith daif dan palsu. Justeru, kajian berbentuk kuantitatif yang melibatkan 361 responden adalah bertujuan untuk melihat sumber amalan pengurusan jenazah dalam masyarakat Islam di Mukim Kutan, Tumpat Kelantan. Beberapa hadith daif dan palsu daripada tema pengurusan jenazah dipilih untuk melihat perkaitannya dengan amalan masyarakat. Hasil kajian membuktikan bahawa sumber yang digunakan oleh masyarakat Islam dalam pengurusan jenazah ialah daripada al-Quran dan sunnah, pandangan Shäfi iyyah, hadith daif, terlalu daif, palsu, serta adat warisan. Namun, tidak dinafikan
\end{abstract}


amalan yang selari dengan al-Quran dan sunnah masih mendominasi dalam pengurusan jenazah selain terdapat juga amalan-amalan yang bercanggah dengan sunnah dan pendapat dalam Shäfi 'iyyah.

Kata kunci: hadith, jenazah, ritual, masyarakat

\section{Pendahuluan}

Rasulullah SAW diutuskan untuk menyampaikan risalah Allah kepada seluruh umat manusia iaitu risalah mentauhidkan Allah dan menjauhi syirik kepadaNya. Rasulullah SAW juga diutuskan untuk mengajar umat manusia segala perkara yang berkaitan dengan kehidupan dunia dan akhirat mereka samada yang berkaitan dengan ibadat atau muamalat. Dalam soal ibadat, tiada perkara yang tidak dijelaskan oleh Nabi SAW melainkan kesemuanya telah ditunjukkan melalui sabdaan dan perlakuan baginda SAW. Sehingga perkara yang dianggap remeh oleh masyarakat seperti qada' hajat turut diperjelaskan oleh Nabi SAW. Justeru, apabila wujud panduan daripada Nabi SAW dalam pengamalan sesuatu ibadat maka tidak wajar umat Islam menambahinya atau menguranginya. Berbeza dalam soal muamalat yang terdedah kepada perubahan berdasarkan maslahah atau mafsadah kepada sesebuah masyarakat. Kepentingan mencontohi Nabi SAW dalam soal ibadat ditegaskan lagi apabila para ulama menetapkan kaedah bahawa sesuatu ibadat tidak boleh dilakukan melainkan datang perintah yang menyuruh melakukannya. Tambahan pula, Ibn kathīr ada menukilkan dalam tafsirnya, terdapat dua syarat penerimaan ibadah iaitu ikhlas kerana Allah yang Esa dan hendaklah betul dan bertepatan dengan syariat. ${ }^{1}$

Kajian membuktikan bahawa masyarakat Islam di Malaysia banyak bergantung kepada adat dan warisan termasuklah dalam persoalan ibadat. Pegangan yang utuh terhadap amalan warisan tersebut adalah dengan kepercayaan akan kesahihan setiap ritual ibadah yang dilakukan sejak turun-temurun. Di samping itu, terdapat juga amalan yang selama ini diyakini mempunyai sandaran daripada Rasulullah SAW. Namun setelah diteliti, dalil yang digunakan bagi mewajarkan amalan tersebut adalah tidak sahih serta bertentangan dengan ajaran Islam yang sebenar.

1 Ismā'īl bin 'Umar bin al-Kathīr al-Qurashī al-Bașrī, Tafsīr al-Qur'ān al- 'Ażīm, ed. Sāmī bin Muhammad Salāmah (t.tp: Dār Ṭayyibah, 1999), 1:385. 


\section{Sumber Pengamalan Hukum Islam di Malaysia}

Bagi masyarakat Islam di Malaysia, mazhab Shāfi'ī telah menjadi mazhab rasmi dalam segala urusan sama ada yang melibatkan amalan atau pentadbiran. Justeru, tidak hairan jika dalam apa sahaja urusan berkaitan hukum maka pandangan Shāfi'iyyah dijadikan hujah dan pegangan oleh semua pihak secara umumnya. Mazhab Shāfi'i 1 di Malaysia juga telah mempunyai penegasan yang kukuh secara perundangan. ${ }^{2}$ Menurut Undang-undang Pentadbiran Agama Islam Selangor, No. 3, Tahun 1952, seksyen 42 (1), peruntukan enakmen jelas menunjukkan bahawa keterikatan fatwa biasanya akan berlaku kepada pandangan muktamad mazhab Shāfi'ī dan kemudiannya beralih kepada pandangan daif dalam mazhab yang sama sebelum berpindah kepada pandangan-pandangan lain daripada baki tiga lagi mazhab sunni dengan berasaskan kepada keperluan kemaslahatan awam dan faedah umum. Sebaliknya jika pandangan Shāfi'iyyah dilihat bertentangan dengan kemaslahatan dan kepentingan awam, pandangan daripada mazhab lain akan diambil sebagai pilihan dalam penentuan fatwa. ${ }^{3}$

Mazhab Shāfi‘ 1 juga telah meninggalkan pengaruh yang besar dalam pendidikan tradisional di Malaysia yang boleh dilihat dalam pelbagai bentuk sistem pengajian yang wujud samada secara formal ataupun tidak ${ }^{4}$ sehingga banyak kitab mazhab Shāfi‘ $\overline{1}$ yang digunakan sebagai rujukan dalam pengajian di pondok-pondok, masjid, surau-surau dan sekolah-sekolah agama. ${ }^{5}$ Malangnya terdapat segelintir golongan yang tidak bertanggungjawab mengambil kesempatan mengeluarkan pelbagai kenyataan yang bercanggah dengan mazhab Shāfi'ī tetapi mendakwa ia merupakan pandangan mazhab terbabit bagi mendapatkan sokongan dan kepercayaan masyarakat.

2 Ahmad Mohamed Ibrahim \& Ahilemah Joned, Sistem Undang-undang di Malaysia (Kuala Lumpur: Dewan Bahasa dan Pustaka, 1986), 12.

3 Noor Naemah Abd. Rahman, "Amalan Fatwa di Malaysia: Antara Keterikatan Mazhab dan Keperluan Tarjih," Jurnal Fiqh, no 4 (2007), 86.

4 Idris Awang dan Tengku Sarina Aini Tengku Kassim, "Pembudayaan Mazhab Syafi'i dalam Masyarakat Islam di Malaysia," Jurnal Fiqh, no. 4 (2007), 160.

5 Ahmad Mohd Salleh, Pendidikan Islam: Falsafah, Sejarah dan Kaedah Pengajaran Pembelajaran (Selangor: Penerbit Fajar Bakti, 2004), 162. 


\section{Skop dan Metodologi Kajian}

Artikel ini bertujuan melihat sumber yang dijadikan rujukan oleh masyarakat Islam dalam pengurusan jenazah. Sebelum kajian lapangan dijalankan, pengkaji mendatangkan dua puluh hadith yang diputuskan sebagai daif dan palsu melalui analisis sanad, pandangan ulama serta komentar-komentar berpandukan kitab jarh

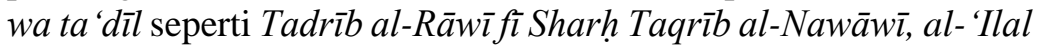
wa Ma'rifah al-Rijāl, Tahdhīb al-Tahdhīb, al-Majrūhīn Min alMuhaddithīn wa al-Du'afā' wa al-Matrūkìn dan lain-lain bagi membuktikan kewujudan hadith-hadith sedemikian lengkap bersanad dalam amalan pengurusan jenazah bukanlah suatu mitos. Namun begitu, kewujudan hadith-hadith tersebut tidak bermaksud secara tuntas ia terus menjadi pegangan dalam amalan pengurusan jenazah masyarakat di kawasan kajian. Justeru, pengkaji memilih beberapa amalan daripada hadith tersebut yang bersesuaian dengan praktikal masyarakat setempat seterusnya digabungkan dengan beberapa amalan lain daripada sumber yang pelbagai termasuk hadith sahih untuk dijadikan soalan kepada responden. Walau bagaimanapun, responden tidak diberitahu darjat dan sumber amalan tersebut bagi mengenalpasti maklum balas mereka terhadap setiap amalan yang dikemukakan.

Kajian berbentuk kuantitatif ini melibatkan 361 responden daripada keseluruhan populasi di kawasan kajian. Seterusnya, perisian Statistical Packages for Social Science digunakan sebagai instrumen bagi menganalisis data-data yang diperoleh. Manakala metod deduktif pula digunakan untuk menyimpul data-data umum kepada kesimpulan-kesimpulan khusus. Bagi analisis hukum hadith pula, pengkaji membuat kesimpulan khusus berdasarkan pelbagai pandangan umum ulama yang berkecimpung dalam kritikan hadith. Namun, pengkaji cenderung mengutamakan pandangan ulama terdahulu berbanding masa kini sekiranya terdapat percanggahan memandangkan ulama terdahulu lebih dekat dengan zaman salaf. Hal ini juga bagi mengiktiraf usaha keras ulama terdahulu yang merupakan golongan awal yang berusaha memelihara sunnah, merantau ke seluruh tempat yang wujud sunnah, menapis hadith antara sahih dan daif, membuat penilaian terhadap perawi, mengkaji kecacatan atau kesilapan pada riwayat serta mengarang buku-buku 
bermanfaat sehingga setiap sunnah dapat diwariskan kepada umat sepanjang zaman. ${ }^{6}$

Lokasi kajian merupakan sebuah Mukim yang berada dalam daerah Wakaf Bharu di bawah jajahan Tumpat, Kelantan. Mukim Kutan yang mempunyai keluasan 498.57 hektar $^{7}$ sebenarnya terbahagi kepada empat lagi pecahan Kutan iaitu Kutan Hulu, Kutan Hilir, Kutan Tengah dan juga Kutan Sungai dengan kapasiti penduduk sekitar 6050 orang. ${ }^{8}$ Majoriti penduduk yang terdiri daripada bangsa Melayu beragama Islam menjadikan penduduk kawasan ini sesuai dijadikan responden kajian. Selain itu, Kutan juga terkenal dinisbahkan kepada tokoh ulama terkemuka yang berasal daripada mukim terbabit iaitu Tok Wan Ali Kutan. ${ }^{9}$ Masyarakat Kelantan secara umumnya didapati cenderung kepada pembelajaran agama sehingga Kelantan dikenali sebagai sebuah negeri Serambi Mekah berikutan kemunculannya sebagai pusat pengajian Islam di Tanah Melayu pada penghujung abad ke-19 sehingga tahun $1940 .{ }^{10} \mathrm{Hal}$ ini menunjukkan lokasi Mukim Kutan

6 Nāṣir bin Hamad al-Faḥd, Manhaj al-Mutaqaddimīn fì al-Tadlīs (Riyadh: Maktabah Aḍ̂ā' al-Salaf, 2001), 46.

7 Jabatan Perancangan Bandar dan Desa Negeri Kelantan, "Rancangan Tempatan Jajahan Tumpat, Jabatan Perancangan Bandar dan Desa Negeri Kelantan" (Perpustakaan Negara Malaysia Data Pengkatalogan - dalam - Penerbitan Rancangan Tempatan Jajahan Tumpat, 2011), 1.

8 Data ini merupakan hasil bancian penduduk pada tahun 2010. Banci Penduduk dan Perumahan Malaysia 2010 (Banci 2010) merupakan banci kelima yang dilaksanakan sejak tertubuhnya Malaysia pada tahun 1963. Banci sebelum ini telah dijalankan pada tahun 1970, 1980, 1991 dan 2000. Banci merupakan projek statistik besar yang dijalankan bagi menghasilkan data yang berguna untuk perancangan dan pelaksanaan dasar pembangunan negara. Lihat laman "Pupulation Distribution and Basic Demographic Characteristic Report 2010," laman sesawang Jabatan Perangkaan Malaysia, dicapai 3 Disember 2018, https://www.dosm.gov.my/v1/index.php?r=column/cthemeByCat\&cat=117\&b ul_id=MDMxdHZjWTk1SjFzTzNkRXYzcVZjdz09\&menu_id=L0pheU43N WJwRWVSZklWdzQ4TlhUUT09 2972011\&catid=130\%3Apopulationdistribution-and-basic-demographic-characteristic-report-population-andhousing-census-malaysia-2010\&Itemid=154\&lang=bm.

9 Mohammad Redzuan Othman, "Masjid al-Haram dan Peranannya dalam Perkembangan Awal Pendidikan dan Intelektualisme Masyarakat Melayu," Jurnal Usuluddin, no. 13 (2001), 71.

10 Najmiah binti Omar dan Zulkifli@Md. Yaakub bin Mohd Yusuf, "Perkembangan Pengajian Tarannum Al-Quran di Terengganu pada Zaman Pra-Merdeka sehingga Tahun 2014," Jurnal Islam dan Masyarakat Kontemporari, no. 13 (2016), 107. 
adalah kawasan terbaik untuk dijadikan kawasan kajian mengenai sumber dan rujukan masyarakatnya dalam pengurusan jenazah mengikut kaedah yang selari dengan ajaran Islam.

\section{Hadith Daif dan Palsu dalam Pengurusan Jenazah}

Sebanyak dua puluh hadith yang berkaitan dengan pengurusan jenazah berjaya dikaji dan dianalisis. Hadith-hadith tersebut diklasifikasikan sebagai daif dan palsu kerana dikenalpasti mempunyai perawi yang bermasalah pada rantaian sanadnya. Hadith-hadith tersebut kemudiannya dibahagikan kepada tiga topik utama mengikut kumpulan amalan yang biasa diamalkan oleh kebanyakan masyarakat Islam. Jadual 1.0 menunjukkan potongan hadith-hadith daif dan palsu dalam pengurusan jenazah yang dimuatkan pada tiga topik yang berbeza seterusnya dipecahkan kepada beberapa subtopik lain.

\section{Jadual 1: Potongan Hadith Daif dan}

Palsu dalam Pengurusan Jenazah

\begin{tabular}{|c|c|c|}
\hline \multirow[t]{2}{*}{ No. } & Teks Hadith & $\begin{array}{l}\text { Hukum } \\
\text { Hadith }\end{array}$ \\
\hline & $\begin{array}{l}\text { a. Hadith Berkaitan Amalan Sebelum Jenazah } \\
\text { Dikebumikan - } \\
\text { i. Kedudukan Imam Semasa Solat Jenazah }\end{array}$ & \\
\hline 1 & 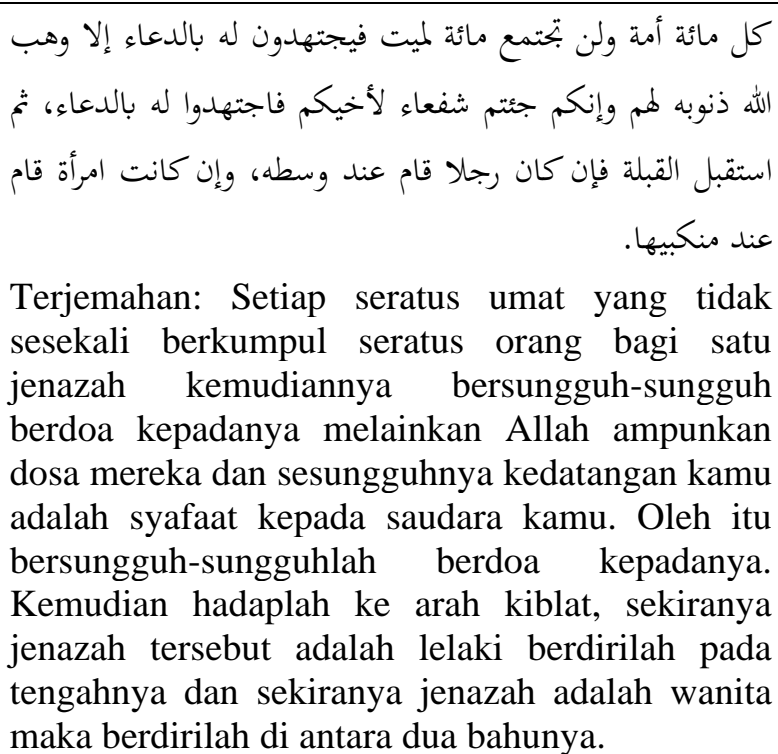 & Daif \\
\hline
\end{tabular}




\begin{tabular}{|c|c|c|}
\hline & $\begin{array}{l}\text { ii. Tahlil Lā Ilāha Illā Allāh yang Mengiringi } \\
\text { Jenazah }\end{array}$ & \\
\hline 2 & $\begin{array}{l}\text { الم يكن يسمع من رسول الله صلى الله عليه وسلم، وهو يمشي خلف إلا قول: لا إله إلا الله، مبديا وراجعا. } \\
\text { الله } \\
\text { Terjemahan: Tidaklah dia mendengar daripada } \\
\text { Rasulullah SAW semasa Baginda berjalan di } \\
\text { belakang jenazah melainkan ucapan lā ilāha illā } \\
\text { Allah, semasa berangkat dan pulang. }\end{array}$ & Palsu \\
\hline 3 & $\begin{array}{l}\text { أكثروا في الجنازة قول لا إله إلا الله. } \\
\text { Terjemahan: Perbanyakkanlah mengucapkan } \\
\text { kepada jenazah lā ilāha illā Allah. }\end{array}$ & Daif \\
\hline & iii. Zikir Semasa Melihat Jenazah & \\
\hline 4 & 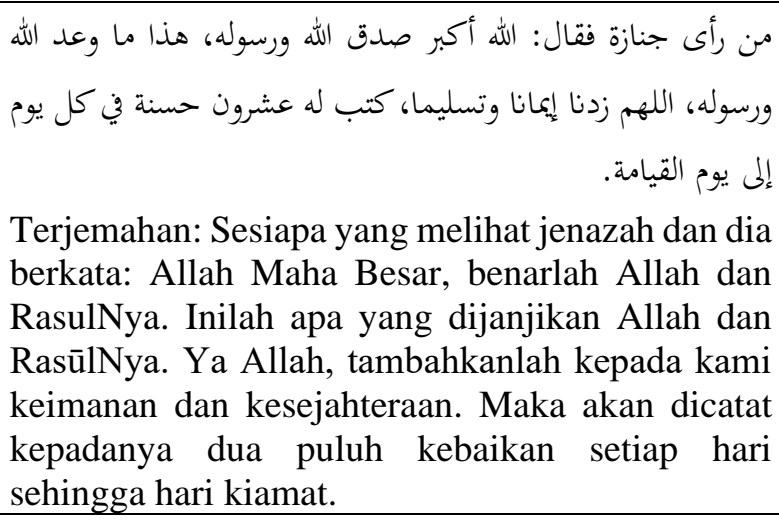 & Palsu \\
\hline & $\begin{array}{l}\text { b. Hadith Berkenaan Pengebumian Jenazah - } \\
\text { i. Zikir Ketika Memasukkan Jenazah ke Dalam } \\
\text { Kubur }\end{array}$ & \\
\hline 5 & 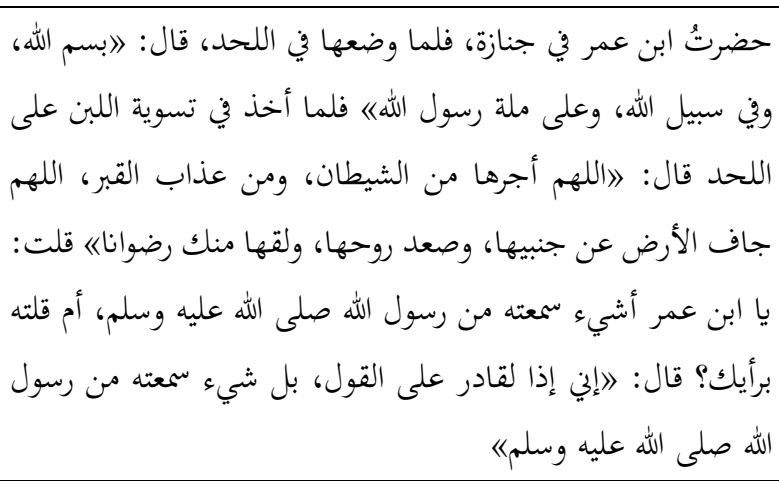 & Daif \\
\hline
\end{tabular}




\begin{tabular}{|c|c|c|}
\hline & $\begin{array}{l}\text { Terjemahan: Aku bersama Ibn 'Umar menghadiri } \\
\text { upacara pengurusan jenazah. Apabila dia } \\
\text { meletakkan jenazah ke dalam lahad, dia berkata: } \\
\text { "Dengan nama Allah, pada jalan Allah dan ke atas } \\
\text { ajaran pesuruh Allah". Apabila dia meratakan } \\
\text { ketulan tanah ke atas lahad, dia berkata: "Ya } \\
\text { Allah, selamatkanlah dia daripada syaitan dan } \\
\text { azab kubur. Ya Allah, lapangkanlah bumi } \\
\text { daripada dua lambungnya, angkatlah rohnya dan } \\
\text { kurniakanlah kepadanya keredaan". Aku berkata: } \\
\text { Wahai Ibn 'Umar, adakah ada sesuatu yang kamu } \\
\text { dengar daripada Rasulullah SAW atau kamu } \\
\text { katakan berdasarkan pandangan kamu? Dia } \\
\text { menjawab: "Aku boleh katakan apa sahaja, } \\
\text { bahkan ini adalah sesuatu yang aku dengarkan } \\
\text { daripada Rasulullah SAW". }\end{array}$ & \\
\hline & $\begin{array}{l}\text { ii. Zikir Semasa Menggenggam Tanah ke Atas } \\
\text { Jenazah }\end{array}$ & \\
\hline 6 & 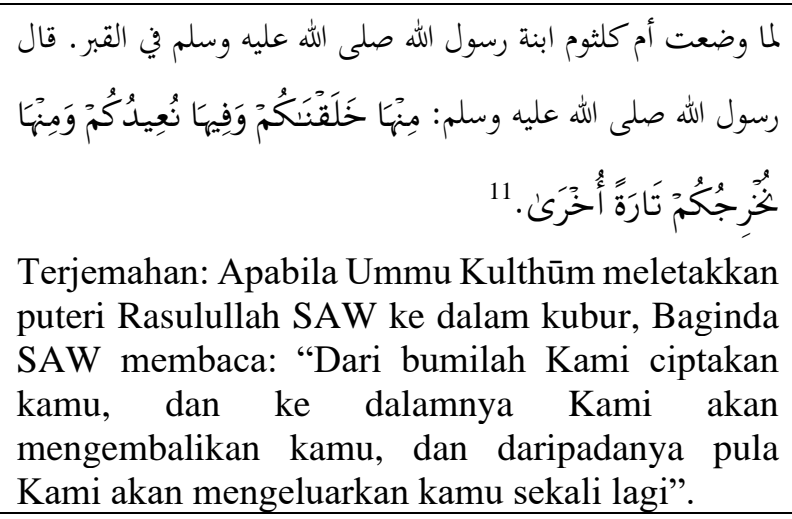 & $\begin{array}{c}\text { Tersangat } \\
\text { daif }\end{array}$ \\
\hline & iii. Talqin Jenazah Selepas Dikebumikan & \\
\hline 7 & 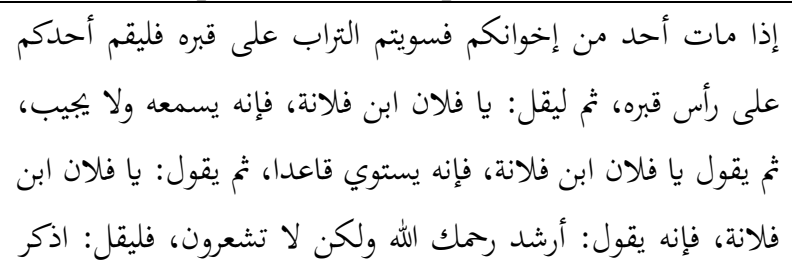 & Daif \\
\hline
\end{tabular}

11 Surah Țaha 20: 55. 


$$
\begin{aligned}
& \text { ما خرجت عليه من الدنيا شهادة أن لا إله إلا الله، وأن محمدا عبده }
\end{aligned}
$$

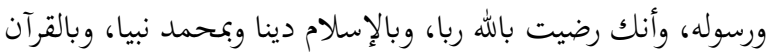

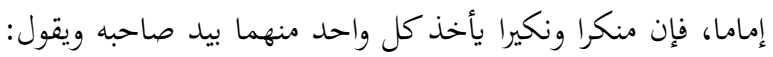

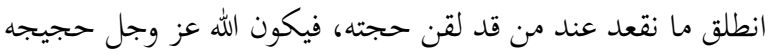

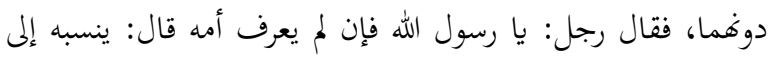

$$
\begin{aligned}
& \text { حواء عليها السلام، يا فلان ابن حواء. }
\end{aligned}
$$

Terjemahan: Apabila meninggal salah seorang daripada saudara kamu, maka ratakanlah tanah ke atas kuburnya dan berdirilah salah seorang daripada kamu pada bahagian kepala kuburnya, kemudian katakanlah: Wahai fulan anak fulanah. Sesungguhnya dia mendengarnya tetapi dia tidak akan menjawab. Kemudian katakanlah: Wahai fulan anak fulanah. Maka dia duduk tegak. Kemudian katakanlah: Wahai fulan anak fulanah. Maka dia berkata: Semoga Allah merahmati kamu tetapi kamu semua tidak merasai apa yang berlaku. Maka katakanlah: Ingatlah apa yang menyebabkan kamu keluar ke dunia iaitu dengan penyaksian bahawa tiada Tuhan selain Allah dan sesungguhnya Muḥammad itu hamba dan utusanNya. Sesungguhnya kamu telah meredai Allah sebagai Tuhanmu, Islam sebagai agamamu, Muhammad sebagai Nabimu dan al-Quran sebagai petunjukmu. Sesungguhnya Munkar dan Nakīr akan mengambil salah satu tangan daripada keduanya dan berkata: Ayuhlah pergi, apa yang kita boleh lakukan lagi terhadap siapa yang telah ditalqinkan hujahnya, jadilah Allah hujahnya tanpa kedua malaikat tesebut. Kemudian berkata seorang lelaki: Wahai Rasulullah SAW, bagaimana sekiranya tidak diketahui ibunya? Baginda bersabda: Nasabkan dia kepada Ḥawwā', wahai fulan anak Hawwā'. 


\begin{tabular}{|c|c|c|}
\hline & iv. Riwayat Mengenai Takziah & \\
\hline 8 & 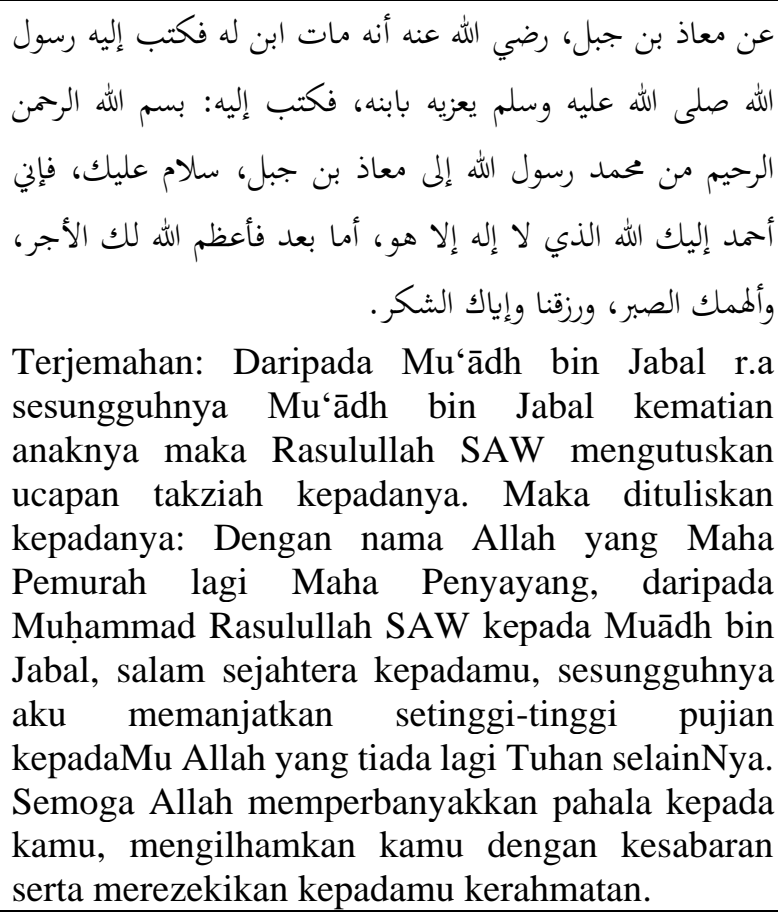 & Palsu \\
\hline 9 & 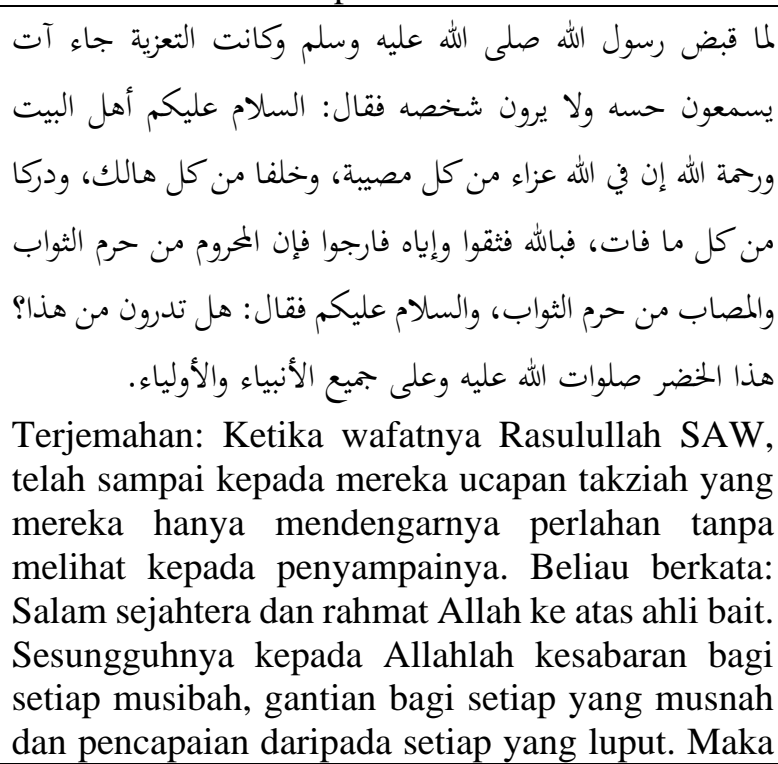 & Daif \\
\hline
\end{tabular}




\begin{tabular}{|c|c|c|}
\hline & $\begin{array}{l}\text { bertaqwalah kepada Allah dan kepadaNyalah } \\
\text { kamu berharap. Sesungguhnya antara } \\
\text { halangannya adalah terhalang mendapat pahala. } \\
\text { Dan orang yang ditimpakan ke atasnya musibah } \\
\text { adalah sesiapa yang terhalang mendapat pahala, } \\
\text { dan salam sejahtera ke atas kamu. Kemudian dia } \\
\text { berkata: Adakah kamu tahu siapakah ini? Inilah } \\
\text { al-Khadir selawat Allah ke atasnya dan ke atas } \\
\text { para Nabi dan wali-wali. }\end{array}$ & \\
\hline & $\begin{array}{l}\text { c. Hadith Berkenaan Aktiviti di Tanah } \\
\text { Perkuburan - } \\
\text { i. Menziarahi Kubur Ibu Bapa Pada Hari Jumaat }\end{array}$ & \\
\hline 10 & $\begin{array}{l}\text { من زار قبر والديه أو أحدهما يوم الجمعة فقرأ يس غفر له. } \\
\text { Terjemahan: Sesiapa yang menziarahi kubur } \\
\text { kedua ibu bapanya atau salah seorang daripada } \\
\text { mereka pada hari Jumaat dan dibacakan Surah } \\
\text { Yasin maka akan diampunkan dosanya. }\end{array}$ & Palsu \\
\hline 11 & $\begin{array}{l}\text { من زار قبر أبويه أو أحدهما في كل جمعة غفر له، وكتب برا. } \\
\text { Terjemahan: Sesiapa yang menziarahi kubur } \\
\text { kedua ibu bapanya atau salah seorang daripada } \\
\text { mereka pada setiap Jumaat maka akan } \\
\text { diampunkan dosanya dan ditulis kepadanya } \\
\text { kebaikan. }\end{array}$ & Daif \\
\hline & ii. Menziarahi Kubur Pada Hari Raya & \\
\hline 12 & $\begin{array}{l}\text { الخروج إلى الجبان في العيدين من السنة. } \\
\text { Terjemahan: Keluar ke pusara pada dua hari raya } \\
\text { adalah daripada sunnah. }\end{array}$ & $\begin{array}{c}\text { Tersangat } \\
\text { daif }\end{array}$ \\
\hline & iii. Membaca al-Quran di Perkuburan & \\
\hline 13 & 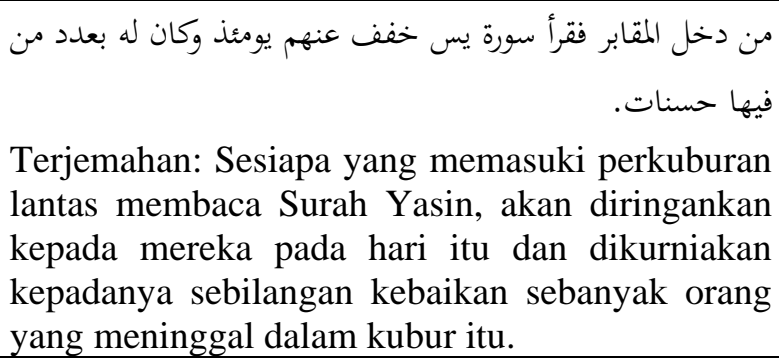 & Palsu \\
\hline
\end{tabular}




\begin{tabular}{|c|c|c|}
\hline 14 & 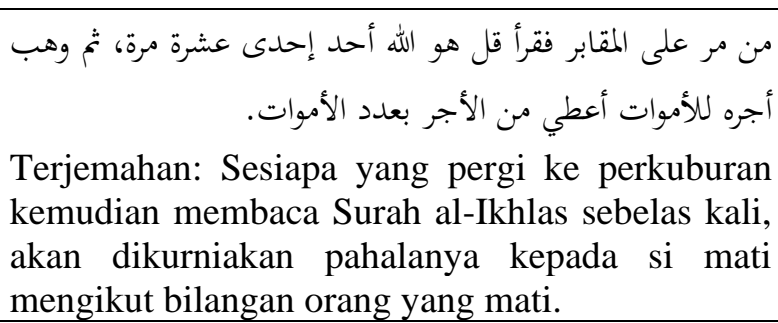 & Palsu \\
\hline 15 & $\begin{array}{l}\text { إذا مات أحدكم فلا تحبسوه، وأسرعوا به إلى قبره، وليقرأ عند رأسه الكتاب، وعند رجليه بخاتمة البقرة في قبره. } \\
\text { Terjemahan: Apabila meninggal salah seorang } \\
\text { daripada kamu, janganlah kamu melengah- } \\
\text { lengahkannya dan segerakanlahnya ke kuburnya. } \\
\text { Kemudian bacakan pada kepalanya dengan } \\
\text { pembukaan Surah al-Fatihah dan pada kedua } \\
\text { keminya dengan penutup Surah al-Baqarah di } \\
\text { kuburnya. }\end{array}$ & $\begin{array}{c}\text { Tersangat } \\
\text { daif }\end{array}$ \\
\hline 16 & 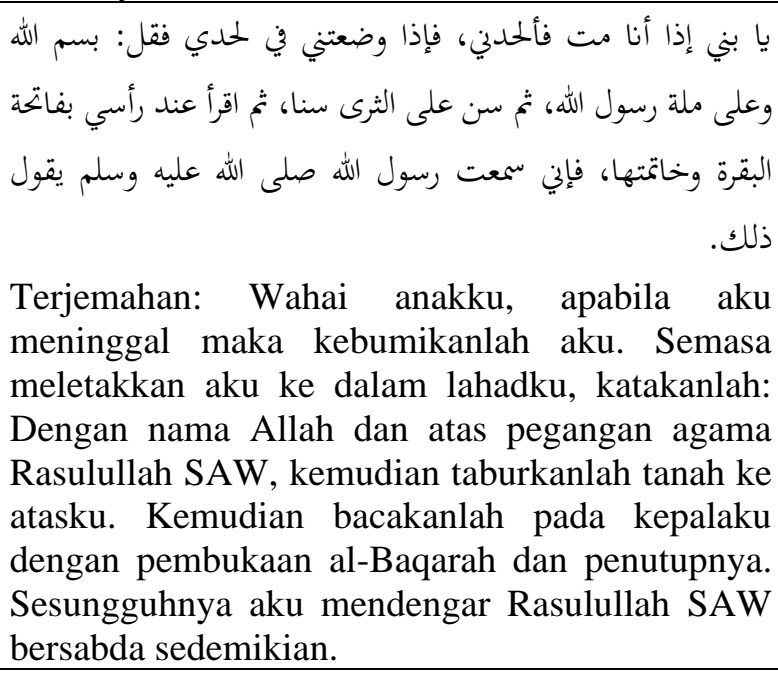 & Daif \\
\hline 17 & $\begin{array}{l}\text { كانت الأنصار إذا مات لهم ميت اختلفوا إلى قبره يقرؤون عنده } \\
\text { Terjemahan: Kaum Anșār apabila terdapat } \\
\text { kematian dalam kalangan mereka, mereka akan } \\
\text { sentiasa mengunjungi kubur si mati dan membaca } \\
\text { al-Quran di sampingnya. }\end{array}$ & Daif \\
\hline
\end{tabular}




\begin{tabular}{|c|c|c|}
\hline \multirow[b]{2}{*}{18} & iv. Menyapu Kubur & \\
\hline & 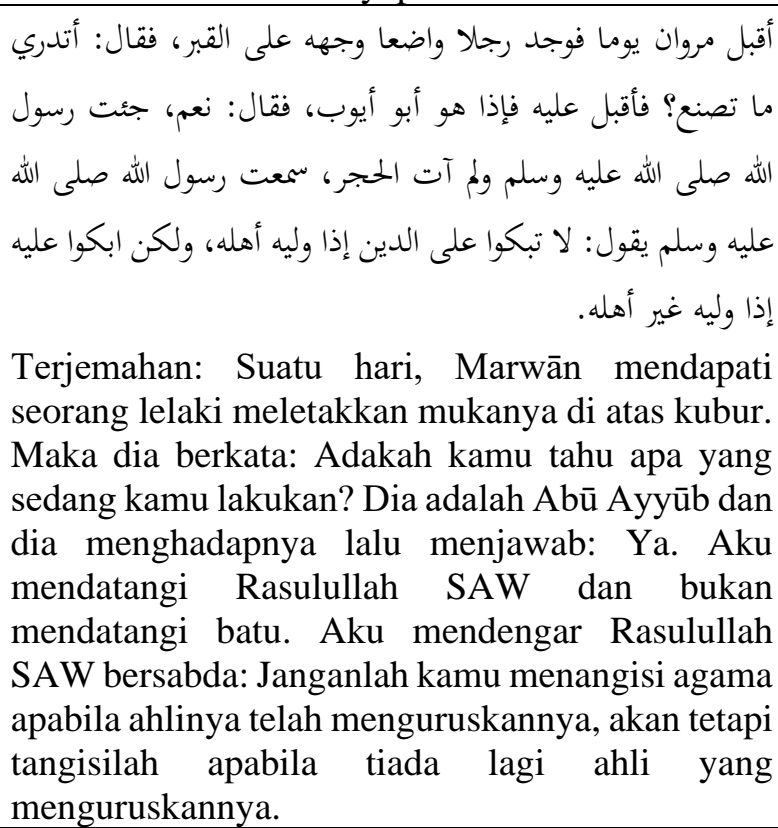 & Daif \\
\hline & v. Memberi Salam kepada Ahli Kubur & \\
\hline 19 & 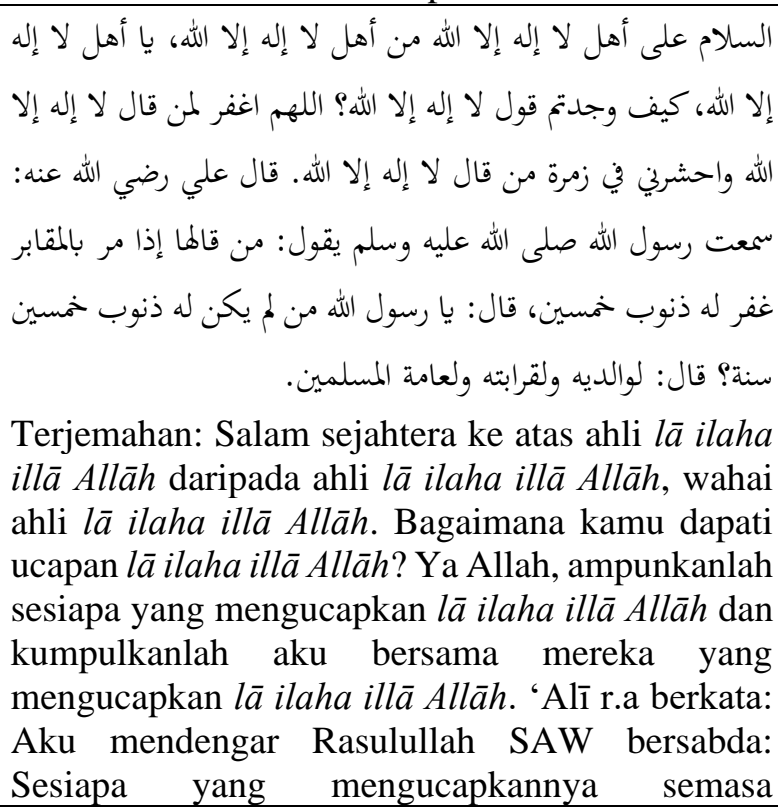 & Palsu \\
\hline
\end{tabular}




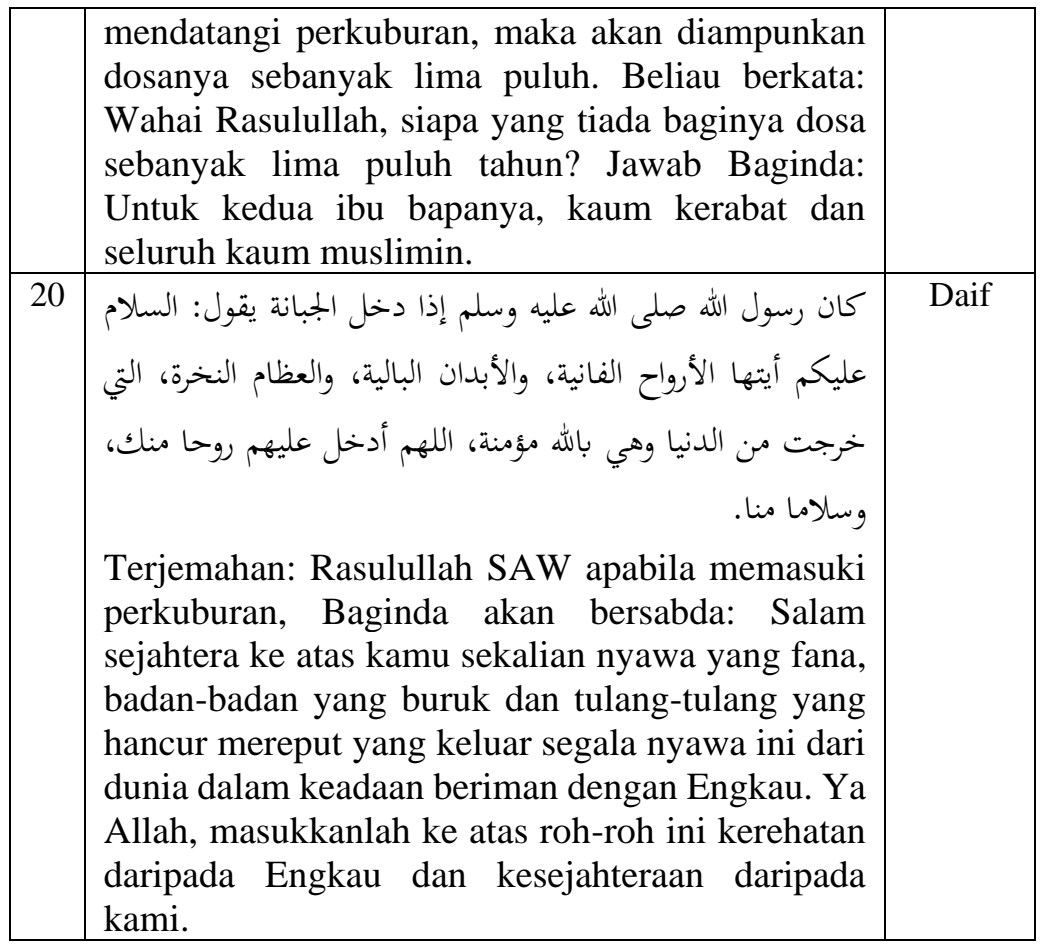

Daripada dua puluh hadith yang dianalisis, terdapat sepuluh hadith daif, tiga hadith yang tersangat daif dan juga tujuh hadith palsu. Seterusnya, sebahagian amalan daripada hadith-hadith tersebut yang sesuai dengan aplikasi masyarakat setempat diekstrak dan digabungkan bersama beberapa amalan pengurusan jenazah lain daripada sumber yang pelbagai lalu dibentuk menjadi borang soal selidik untuk dikemukakan kepada masyarakat di kawasan kajian. Tahap kesahihan, status mahupun darjat amalan-amalan pengurusan jenazah yang dikemukakan tidak didedahkan bagi mendapatkan reaksi sebenar responden terhadapnya.

\section{Dapatan Kajian}

Hasil kajian menunjukkan masyarakat di kawasan kajian sangat prihatin terhadap sumber pengetahuan pengurusan jenazah yang dimiliki. Buktinya rata-rata responden tahu dari mana datangnya pengetahuan mereka. Selain itu, responden juga mampu menjelaskan samada maklumat yang dimiliki bertepatan dengan sumber Islam yang sebenar atau sebaliknya. Kesediaan responden 
untuk menyemak maklumat dan memperbetulkan amalan yang tidak autentik juga menunjukkan keseriusan dalam memastikan keaslian ilmu dan ritual ibadah yang dilakukan.

\section{a. Sumber Pengetahuan}

Berdasarkan analisis terhadap sumber pengetahuan responden dalam pengurusan jenazah, didapati $86.4 \%$ responden menjawab sumber pengetahuan mereka adalah daripada amalan turuntemurun. Dapatan ini bertepatan dengan beberapa kajian ${ }^{12}$ lain yang telah dilakukan sebelum ini. Amalan yang diwarisi turun-temurun ini lebih terdedah kepada pengaruh adat dan budaya yang mungkin bercanggah dengan kaedah Islam yang sebenar. ${ }^{13}$ Dapatan ini juga membuktikan pengetahuan yang diwarisi lebih senang disampaikan dan lebih yakin untuk diamalkan.

\section{b. Ketepatan dengan Ajaran Islam}

Majoriti responden iaitu seramai $83.9 \%$ bersetuju amalan masyarakat setempat adalah selari dengan sumber Islam yang sebenar. Kesepakatan dalam pilihan jawapan ini dapat dilihat dengan peratusan lebih $90 \%$ tidak bersetuju untuk menyatakan amalan yang dilakukan adalah sekadar ikutan atau bercanggah dengan sumber Islam yang sebenar. Justeru daripada kaca mata responden, amalan pengurusan jenazah yang diamalkan masyarakat setempat adalah tidak bercanggah sama sekali dengan sumber Islam yang sebenar.

\section{c. Penggunaan Hadith Palsu}

Seterusnya $98.9 \%$ responden berpendapat amalan-amalan mereka dalam pengurusan jenazah tidak bersandarkan hadith palsu. Ini menunjukkan keyakinan mereka terhadap kualiti amalan yang dilakukan adalah daripada sumber yang boleh dipercayai.

12 Yulyenita, "Tradisi Penyelenggaraan Jenazah di Pulau Tengah Kecamatan Keliling Danau Kabupaten Ditinjau dari Hukum Islam” (Disertasi, Jabatan Fiqh \& Usul, Akademi Pengajian Islam, Universiti Malaya, 2009).

13 Hamidah Abdul Wahab et al., "Eufemisme Pengurusan Jenazah Masyarakat Melayu Sarawak: Analisis Semantik Kognitif,” Jurnal Bahasa 16, no. 1 (2016). 


\section{d. Pengesahan Maklumat}

Dalam konteks interaksi dengan sumber yang meragukan pula, majoriti responden dengan peratusan sebanyak $84.5 \%$ memilih untuk mendapatkan pengesahan maklumat daripada pakar seperti para ustaz dan imam sebelum beramal dengannya. Selain itu, kesemua responden menunjukkan sikap berhati-hati dengan maklumat yang diperolehi apabila bersepakat untuk tidak menyebarkan maklumat tanpa sebarang semakan.

\section{e. Kesediaan Membetulkan Amalan}

Peratusan tertinggi $92 \%$ responden menunjukkan kesediaan mereka memperbetulkan amalan yang bercanggah dengan sumber yang sebenar kemudiannya diikuti dengan $4.2 \%$ responden yang tidak pasti samada mahu memperbetulkan amalan tersebut ataupun tidak. Namun begitu, terdapat juga $0.8 \%$ responden yang tetap tidak mahu mengubah pendirian mereka sekaligus ingin meneruskan amalan yang bercanggah dengan sumber yang sebenar. Jangkaan asal adalah $100 \%$ responden bersedia untuk memperbetulkan amalan mereka yang bercanggah dengan sumber yang sebenar, namun hasil menunjukkan terdapat juga maklum balas yang sebaliknya. Ini membuktikan sememangnya wujud segelintir masyarakat yang berpada dengan amalan sedia ada tanpa berhasrat untuk meningkatkan kualiti amalan tersebut walaupun ternyata terdapat kesilapan jelas padanya. Walau bagaimanapun, hasil analisis dengan peratusan lebih $90 \%$ ini sudah cukup untuk menjadi isyarat bahawa majoriti masyarakat masih terbuka untuk mengubah amalan-amalan yang sekian lama menjadi pegangan mereka disebabkan percanggahan amalan tersebut dengan sumber Islam yang sebenar.

\section{Sumber Amalan Masyarakat Islam dalam Pengurusan Jenazah} Melalui analisis terhadap soalan soal selidik yang telah diedarkan, amalan pengurusan jenazah masyarakat di Mukim Kutan, Tumpat Kelantan boleh dibahagikan kepada beberapa sumber seperti berikut:
a. Hadith Sahih
b. Pandangan Shāfi'iyyah
c. Hadith Mardud: i. Hadith Daif; ii. Terlalu Daif; iii. Palsu
d. Adat Warisan 


\section{Rajah 1: Sumber Amalan Masyarakat}

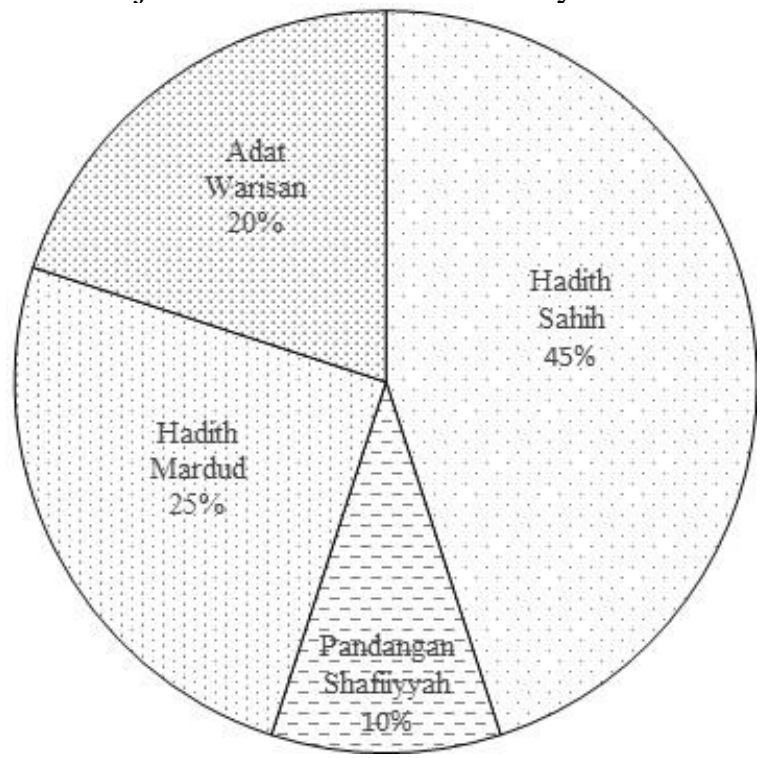

Reaksi responden menunjukkan sebanyak $45 \%$ amalan yang dilakukan dalam pengurusan jenazah adalah selari dengan hadith sahih. Peratusan kedua tertinggi merupakan amalan yang bersumberkan daripada hadith mardud sebanyak $25 \%$ mewakili pecahan $10 \%$ hadith daif, $10 \%$ hadith palsu dan 5\% hadith yang terlalu daif. Amalan pengurusan jenazah masyarakat daripada adat warisan berada pada kedudukan ketiga tertinggi dengan peratusan $20 \%$ diikuti dengan peratusan paling sedikit sebanyak $10 \%$ amalan daripada pandangan Shāfi'iyyah.

Sejumlah 55\% daripada keseluruhan sumber amalan adalah terdiri daripada hadith sahih dan pandangan Shāfi'iyyah. Baki 45\% amalan lagi adalah daripada amalan yang bersumberkan hadith mardud dan juga adat warisan. Daripada keseluruhan soalan yang dikemukakan, terdapat sembilan amalan responden yang selari dengan hadith sahih, lima amalan terdiri daripada hadith mardud, empat amalan daripada adat warisan dan dua lagi bersesuaian dengan pandangan Shāfi'iyyah.

Berdasarkan maklum balas responden terhadap amalanamalan pengurusan jenazah yang dikemukakan menunjukkan peratusan besar amalan yang dilakukan adalah selari dengan sunnah dan pandangan ulama mazhab dengan peratusan sebanyak $55 \%$. 


\section{Amalan Masyarakat yang selari dengan Hadith Sahih}

Antara amalan yang selari dengan hadith sahih dalam pengurusan jenazah di kawasan kajian adalah mengkafankan jenazah menggunakan tiga helai kain putih bagi jenazah lelaki ${ }^{14}$ dan lima helai bagi jenazah perempuan. ${ }^{15}$ Bagi kedudukan imam semasa solat jenazah pula, pengkaji mendapati praktikal imam adalah sebagaimana yang dilakukan Rasulullah SAW iaitu berdiri pada bahagian kepala bagi lelaki dan tengah bagi jenazah wanita semasa solat jenazah. ${ }^{16}$ Seterusnya amalan responden yang menghantar ucapan takziah apabila menerima khabar kematian ${ }^{17}$ dan juga menyegerakan jenazah ke perkuburan ${ }^{18}$ adalah bertepatan sebagaimana yang dinyatakan dalam hadith Rasulullah SAW. Terdapat juga amalan-amalan yang pengkaji kelaskan sebagai selari dengan sunnah apabila responden meninggalkan amalan tersebut. Antaranya adalah tidak melakukan azan setelah jenazah diletakkan ke dalam kubur, ${ }^{19}$ tidak melakukan talqin dengan tujuan supaya

14 Hadith riwayat al-Bukhārī, Bāb al-Thiyāb al-Bịd li al-Kafn, no. Hadith 1264. Lihat Muhammad bin Ismā‘̄̄l bin Ibrāhīm bin Mughīrah al-Bukhārī, Sāḥ̄h alBukhārī, ed. Muhammad Zuhayr Nāṣir al-Nāșir (t.tp.: Dār Ṭūq al-Najāh, 2000), 2:75.

15 Hadith riwayat Abū Dāwūd, Bāb fĩ Kafan al-Mar'ah, no. Hadith 3157. Lihat Sulaymān bin al-Ash'ath bin Isḥāq bin Bashīr bin Shidād bin 'Amr al-Azdī alSijistānī, Sunan Abū Dāud, ed. Muḥammad Muḥȳ̄ al-Dīn 'Abd al-Hamīd (Beirut: al-Maktabah al-'Așriyyah, t.t.), 3:200.

16 Hadith riwayat al-Bukhārī, Bāb Ayna Yaqūmu Min al-Mar'ah wa al-Rajul, no. Hadith 1332. Lihat Muhammad bin Ismā‘īl bin Ibrāhīm bin Mughīrah alBukhārī, Sāḥ̄ḥ al-Bukhārī, ed. Muḥammad Zuhayr Nāṣir al-Nāṣir (t.tp.: Dār Ṭūq al-Najāh, 2000), 2: 89.

17 Hadith riwayat Ibn Mājah, Bāb Mā Jāa fĩ Thawāb Min 'Azzā Musāāā, no. Hadith 1601. Lihat Abū 'Abd Allāh Muḥammad bin Yazid al-Rabi' bin Mājah al-Qazwīnī, Sunan Ibn Mājah, ed. Muhạmmad Fu'ād 'Abd al-Bāqī (t.tp.: Dār al-Ihyeā' al-Kutub al-'Arabiyah, t.t.), 1: 511.

${ }^{18}$ Hadith riwayat al-Bukhārī, Bāb al-Sur'ah bi al-Jināzah, no. Hadith 1315. Lihat Muḥammad bin Ismā‘̄il bin Ibrāhīm bin Mughīrah al-Bukhārī, Sāḥịh alBukhārī, ed. Muhammad Zuhayr Nāṣir al-Nāṣir, (t.tp.: Dār Ṭūq al-Najāh, 2000), 2:86.

19 Fatāwā al-Lujnah menyatakan tidak thabit kepada Nabi SAW dan para sahabat Baginda SAW mengiringi jenazah bersama tahlil dan azan selepas meletakkan jenazah di dalam lahad. Al-Lujnah al-Dāimah li al-Buhūth al-'Ilmiyyah wa alIftā', Fatāwā al-Lujnah al-Dāimah-al-Majmū'ah al-Ūlā, 9: 22. 
jenazah terlepas daripada soal jawab kubur, ${ }^{20}$ tidak meletakkan muka di atas kubur dan menciumnya serta tidak duduk atau bersandar pada kubur. ${ }^{21}$ Melakukan amalan tersebut adalah bertentangan dengan praktikal Rasulullah SAW manakala meninggalkannya adalah lebih mendekati sunnah Baginda SAW.

\section{Amalan Masyarakat yang Berpandukan Pandangan Shāfi'iyyah}

Amalan responden yang berpandukan pandangan Shāfi'iyyah antaranya berkaitan kedudukan jenazah yang diletakkan menghadap kiblat semasa dikebumikan dan juga amalan meletakkan pelepah pokok atau menanam pokok di atas kubur.

Menurut majoriti ulama Shāfi'iyyah, wajib mengiringkan jenazah ke sebelah kanan dengan menghadapkan ke arah kiblat dan pipinya sunat dikenakan tanah. Sekiranya tidak dihadapkan ke arah kiblat dan kubur telah pun ditimbus, maka wajib digali semula untuk menghadapkan jenazah ke arah kiblat jika jenazah belum berubah keadaan. ${ }^{22}$ Sekiranya sudah berubah, maka tidak boleh lagi digali. ${ }^{23}$ Dalam pada itu, terdapat juga pandangan ulama mazhab yang sama tidak mewajibkannya. Al-Nawāwī menukilkan pandangan Abū al-Ṭayȳib daripada kitab al-Mujarrad bahawa menghadapkan jenazah ke arah kiblat di dalam liang lahad adalah sunnah. Oleh kerana itu, jika tidak dilakukan maka sunnah digali semula dan dihadapkan ke arah kiblat. Namun, perkara tersebut tidaklah menjadi kewajipan. ${ }^{24}$ Walaubagaimana pun, tiada ucapan khusus daripada Rasulullah SAW supaya jenazah dikebumikan

20 Beberapa golongan Shāfi‘iyyah berpandangan mereka menyukai amalan talqin setelah jenazah dikebumikan. Namun begitu, talqin yang dilakukan bukanlah dengan tujuan supaya jenazah terlepas daripada soal jawab kubur.

Lihat Abū Zakariyyā Muhyī al-Dīn Yaḥyā bin Sharf al-Nawāwī, al-Majmū ‘ Sharh al-Muhadhdhab (t.tp.: Dār al-Fikr, t.t.), 5: 303.

21 Al-Wansharīsī ada menyebut mengucup kubur lelaki soleh adalah suatu pembahruan. Abū al-'Abbās Aḥmad bin Yaḥyā al-Wansharīsī, Al-Mi'yār alMa 'rab wa al-Jāmi 'al-Maghrab 'an Fatāwā Ahl Ifrīqiyyah wa al-Andalus wa al-Maghrab, ed. Dr Muḥammad Ḥujjājī (Beirut: Dār Maghrab al-Istāmī, 1979), 2:490.

22 Zulkifli Mohamad al-Bakri, Fiqh Jenazah: Panduan Pengurusan, Hukum \& Fatwa (Negeri Sembilan: Pustaka Cahaya Kasturi Sdn. Bhd., 2017), 56.

23 Abū Zakariyyā Muhȳī al-Dīn Yahyyā bin Sharf al-Nawāwī, Ruḍh al-Ṭālibīn wa 'Umdah al-Muftiyyīn (Beirut: al-Maktab al-Islāmī, 1991), 2: 134.

24 al-Nawāwī, Ruḍah al-Tālibīn wa 'Umdah al-Muftiyyīn, 2:135. 
dalam keadaan menghadap kiblat. Namun terdapat satu hadith yang dikaitkan sebagai isyarat orang meninggal perlu dihadapkan ke arah kiblat apabila seorang lelaki pernah bertanyakan Rasulullah SAW berkenaan dosa-dosa besar. Lalu Baginda SAW menjawab:

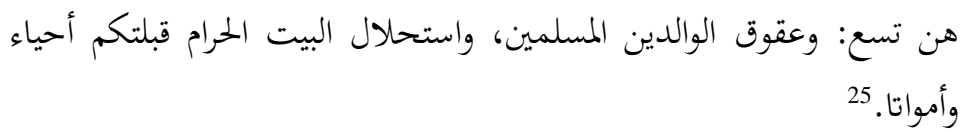

Terjemahan: Semuanya ada sembilan. Derhaka kepada kedua ibu bapa yang muslim dan menghalalkan darah di masjid haram yang merupakan kiblat kamu semasa hidup dan mati.

Amalan meletakkan pelepah di atas kubur pula dihukumkan sebagai sunat oleh ulama Shāfi'iyyah. Ulama Shāfi'iyyah berpandangan sunat diletakkan pelepah tamar atau seumpamanya di atas kubur. Individu lain tidak dibolehkan mengambilnya dari atas kubur sebelum ia kering memandangkan manfaatnya akan hilang setelah kering. ${ }^{26}$ Pandangan seterusnya pula menyatakan amalan ini dikhususkan kepada Rasulullah SAW sahaja. Ini berdasarkan beroleh keberkatan dan doa daripada Rasulullah SAW agar diringankan azab kepada dua penghuni kubur sebagaimana yang dinyatakan dalam sebuah hadith sahih. ${ }^{27}$ Baginda Rasulullah SAW juga seolah-olah menjadikan tempoh lembab pelepah dalam hadith tersebut sebagai masa diringankan azab terhadap mereka. ${ }^{28}$

\section{Amalan Masyarakat yang Bersumberkan Hadith Daif dan Palsu}

Hadith daif, terlalu daif dan palsu merupakan kelompok hadith mardud. Dalam kajian ini, terdapat dua amalan responden yang

25 Hadith riwayat Abī Dāwūd, Bāb Mā Jā'a fī Akl Māl al-Yatīm, no. Hadith 2875. Lihat Sulaymān bin al-Ash'ath bin Ishāā bin Bashīr bin Shidād bin 'Amr alAzdī al-Sijistāni, Sunan Abū Dāud, ed. Muḥammad Muḥȳi al-Dīn 'Abd alḤāmīd (Beirut: al-Maktabah al-'Așriyyah, t.t.), 3:115. Hadith ini direkodkan sebagai hasan.

26 Shams al-Dīn Muḥammad bin Aḥmad al-Khațīb al-Sharbīnī, al-Mughn̄̄ alMuḥtāj Ilā Ma 'rifah Ma 'ānī al-Fāz al-Minhāj (t.tp: Dār al-Kutub al-'Ilmiyyah, 1994), 2:56.

27 Hadith riwayat al-Bukhārī, Bāb al-Jarīd 'Alā a-Qabr, no. Hadith 1361. Lihat Muhammad bin Ismā‘̄il bin Ibrāhīm bin Mughīrah al-Bukhārī, Sāḥ̄h alBukhārī, ed. Muḥammad Zuhayr Nāṣir al-Nāṣir (t.tp.: Dār Ṭūq al-Najāh, 1422H), 2: 95.

${ }^{28}$ Abū Sulaymān bin Muhammad bin Ibrāhīm bin al-Khaț̣āb al-Bustān̄ī, Ma 'álim al-Sunan (Halb: al-Mațba'ah al-'Ilmiyyah, 1932), 19. 
bersumberkan hadith daif iaitu bersama dalam majlis bacaan talqin setelah jenazah dikebumikan dan juga memperbanyakkan ucapan $l \bar{a}$ ilaha illa Allāh kepada jenazah. Walaupun amalan membaca talqin termasuk dalam kategori hadith daif, namun ia masih bertepatan dengan pandangan minoriti ulama Shāfi 'iyyah. Ulama tersebut berpandangan mereka menyukai amalan talqin setelah jenazah dikebumikan, iaitu apabila seorang individu berdiri di sisi kepala kubur jenazah dan berkata wahai fulan anak fulan hingga seterusnya. ${ }^{29}$ Ini menunjukkan hanya seorang wakil yang akan membaca talqin manakala yang lain sekadar bersama dan mendengar talqin dibaca.

Manakala bagi ucapan lā ilaha illā Allāh yang disarankan Rasulullah SAW pula adalah untuk diajarkan kepada orang sakit semasa di ambang kematian. ${ }^{30}$ Ulama Shāfíiyyah dan lain-lain berpandangan hendaklah berlemah-lembut semasa mengajarkan kalimah tersebut. Tidak sepatutnya orang sakit didesak untuk menyebutnya, sebaliknya perlu disebut di sampingnya sekadar dia mendengar dan sedar untuk mengucapkannya. Apabila sudah diucapkan sekali, maka kalimah tersebut tidak perlu diulanginya lagi melainkan dia bercakap selepasnya. ${ }^{31}$ Namun begitu, bukanlah suatu anjuran untuk memperbanyakkan ucapan lā ilaha illā Allāh setelah orang sakit tersebut sudah meninggal dunia.

Amalan daripada hadith yang terlalu daif yang dilakukan responden adalah menziarahi perkuburan pada waktu yang dikhususkan iaitu hari raya. Abū al-Qāsim al-'Abdūsî̀ $\overline{1}^{32}$ menyebut, penetapan ziarah kubur kaum kerabat pada hari raya adalah rekaan yang dahsyat sekiranya disertai dengan keyakinan terdapat kelebihan berbanding hari lain. Namun, perbuatan berkenaan dibolehkan sekiranya tidak mempunyai kelapangan pada hari lain.

29 Abū Zakariyyā Muḥȳ̄ al-Dīn Yaḥyā bin Sharf al-Nawawī, al-Majmū ‘ Sharḥ alMuhadhdhab (t.tp.: Dār al-Fikr, t.t.), 5: 303.

30 Al-Nawawī, al-Majmū' Sharh al-Muhadhdhab, 5:303.

31 Zakariyyā al-Anșāī̄, Fath al-Wahhāb Sharh Minhaj al-Ṭullāb (Beirut: Dār alFikr, t.t.), 2: 135.

32 Beliau adalah Abū al-Qāsim bin Mūsā bin Mu'țī yang terkenal dengan al'Abdūsīy al-Shaykh al-Ḥāfiz al-Muḥaddith, meninggal di Tunisia tahun 837. Aḥmad bin Yaḥyā al-Wansharīsī, Wafayāt al-Wansharīsī, ed. Muhammad Ḥujjajī (Beirut: Dār al-Gharb al-Islāmī, 1995), 2:744. 
Al-Qāḍ̄ Abū al-Walīd bin Rushd turut menukilkannya dalam Jāmi ‘ al-Bayān. ${ }^{33}$

Seterusnya terdapat dua bentuk amalan responden yang bersumberkan hadith palsu iaitu mengiringi jenazah ke perkuburan sambil membaca zikir lā ilaha illā Allāh dan juga membaca Surah Yasin di kubur ibu bapa pada hari Jumaat. Amalan mengiringi jenazah ke perkuburan sambil membaca zikir là ilaha illā Allāh lā ilaha illā Allāh dilihat bertentangan dengan sebuah athār yang menunjukkan Rasulullah SAW banyak berdiam diri semasa mengiringi jenazah. ${ }^{34}$ Menurut al-Nawāwī, anjuran kepada orang yang mengiringi jenazah adalah dengan menyibukkan diri mengingati Allah dan merenungkan apa yang akan ditemui setelah kematian, keadaan tempat kembalinya, apa yang akan diperolehinya di sana serta merenungkan kematian sebagai penghujung dunia. ${ }^{35}$

Bagi amalan membaca Surah Yasin di kubur ibu bapa pada hari Jumaat pula, ternyata tiada hujah khusus yang melarang amalan tersebut. Namun penetapan surah untuk dibaca serta waktu ziarah yang tertentu tidak thabit Rasulullah SAW ada melakukannya secara perkataan, perbuatan mahupun pengakuan. Tambahan pula, Ibn Hajar berpandangan kubur bukanlah tempat untuk melakukan ibadah. $^{36}$

\section{Amalan Masyarakat yang Bersumberkan Adat Warisan}

Rantau Nusantara terkenal sebagai kawasan yang memiliki keunikan dari segi kearifan tempatan yang membezakannya dengan

33 Abū al-'Abbās Aḥmad bin Yahyāa al-Wansharīsī, al-Mi yār al-Mu'rab wa alJāmi ' al-Maghrib 'an Fatāwā Ahl Ifrīqiyyah wa al-Andalus wa al-Maghrib, ed. Dr Muḥammad Ḥujjajī dan lain-lain (Beirut: Dār al-Gharb al-Islāmīi, 1988), $1: 123$.

34 Abū 'Abd al-Raḥman 'Abd Allāh bin al-Mubārak bin Wāḍiḥ al-Ḥanẓalī, alZuhd, ed. Ḥabīb al-Raḥman al-A'zamī (Beirut: Dār al-Kutub al-'Ilmiyyah, t.t.), 82. Hadith ini mempunyai shawāhid yang menguatkannya.

35 Abū Zakariyyā Muḥȳī al-Dīn Yaḥyā bin Sharf al-Nawawī, al-Adhkār, ed. 'Abd al-Qādir al-Arnā'ūt (Beirut: Dār al-Fikr, 1994), 160.

36 Aḥmad bin 'Alī bin Muḥammad bin Aḥmad bin Ḥajar al-'Asqalānī, Fath alBārī Sharh Șaḥīh al-Bukhārīe ed. Muḥammad Fu'ād 'Abd al-Bāqī, Muhị alDīn al-Khațīb dan 'Abd al-'Azīz bin 'Abd Allah bin Bāz (Beirut: Dār alMa'rifah, 1379H), 1: 529. 
kawasan umat Islam yang lain. ${ }^{37}$ Konsep kearifan tempatan bermaksud kefahaman mendalam yang bertentangan dengan konsep intelektual barat. ${ }^{38}$ Namun begitu, kearifan tempatan adalah lebih umum berbanding uruf dan adat. ${ }^{39}$ Penentuan kearifan tempatan dalam hukum Islam adalah masih mengambil kira kaedahkaedah dan prinsip-prinsip umum. ${ }^{40}$ Justeru, kedudukan kearifan tempatan selagi mana tidak menjejaskan prinsip akidah dan keimanan, tidak merosakkan akal, tidak menimbulkan kerosakan serta tidak jelas bercanggah dengan nilai-nilai syariah, maka ia boleh dikategorikan sebagai harus. ${ }^{41}$ Ini menunjukkan Islam bukanlah agama yang memusuhi adat mahupun kearifan tempatan. Lebih-lebih lagi di persekitaran alam Melayu yang sangat kaya dengan adat dan tradisi sehingga pelbagai pepatah dan ungkapan terbina bagi menggambarkan utuhnya pegangan masyarakat Melayu kepada budaya turun-temurun. Namun, mengaitkan semua amalan daripada adat warisan dengan kearifan tempatan bukanlah suatu tindakan yang tepat kerana terdapat juga adat yang diamalkan tidak mempunyai sumber yang jelas malah ada yang bertentangan dengan sumber yang hakiki. Adat warisan yang bertentangan dengan syariat perlu ditinggalkan walaupun kesannya akan dicela masyarakat. Sejarah menunjukkan meninggalkan tradisi yang bercanggah dengan syariat bukanlah suatu perkara yang mustahil. Buktinya amalan mandi safar yang masyhur dalam kalangan masyarakat Melayu suatu ketika dahulu dengan tujuan untuk menolak bala sudah tidak diamalkan generasi kini. Justeru, kearifan tempatan boleh dan mesti diperkemaskan manakala kemungkaran tempatan wajar ditinggalkan.

Dalam kajian ini, terdapat empat amalan responden yang bersumberkan daripada adat warisan tanpa sebarang hujah yang sahih. Amalan-amalan tersebut adalah berdoa dan wirid selepas

37 Azyumardi Azra, Renaisans Islam Asia Tenggara: Sejarah Wacana dan Kekuasaan (Bandung: PT Remaja Rosdakarya, 1999), 5.

38 Rahimin Affandi Abdul Rahim et.al, "Islam dan Kearifan Tempatan di Alam Melayu: Analisis Kritikal,” Jurnal Jati, no. 18 (2013), 224.

39 Muhammad Ikhlas Rosele dan Abdul Karim Ali, "Konsep Kearifan Tempatan Menurut Perspektif Hukum Islam,” Jurnal Fiqh, no 16 (2019), 17.

40 Muhammad Ikhlas Rosele dan Abdul Karim Ali, "Konsep Kearifan Tempatan Menurut Perspektif Hukum Islam," 18.

${ }^{41}$ Muhammad Ikhlas Rosele dan Abdul Karim Ali, "Konsep Kearifan Tempatan Menurut Perspektif Hukum Islam," 19. 
menunaikan solat jenazah, memayungi jenazah sepanjang perjalanan ke perkuburan, meletakkan batu nisan dan membina belindan di atas kubur serta mengadakan kenduri arwah dan menjemput orang ramai menghadirinya. Mendoakan jenazah pada takbir-takbir solat jenazah merupakan salah satu kewajipan memandangkan tujuan solat jenazah adalah untuk mendoakan si mati. Malah al-Shāfi'‘ $\bar{i}$ dan ulama Shāfi'iyyah turut bersepakat doa kepada jenazah adalah salah satu kewajipan dan menjadi rukun dalam solat jenazah. ${ }^{42}$ Walau bagaimanapun, amalan membaca doa dan wirid selepas solat jenazah tidak dinyatakan dalam mana-mana kitab fiqh. Secara tidak langsung menunjukkan amalan ini merupakan suatu adat yang baharu diwujudkan. Tambahan pula, wirid dan berdoa selepas solat jenazah secara tidak langsung akan melengah-lengahkan urusan jenazah ke perkuburan. Situasi ini jelas bercanggah dengan anjuran Rasulullah SAW supaya menyegerakan jenazah ke perkuburan. ${ }^{43}$

Menutup aurat jenazah adalah perkara yang sangat ditekankan. Namun begitu, menutup aurat dan memayungkan jenazah sehingga ke perkuburan dengan niat untuk memuliakan jenazah adalah dua perkara yang berbeza. Perbuatan memayungkan jenazah ke perkuburan adalah dimakruhkan melainkan jika dilakukan dengan tujuan untuk memayungi mereka yang hadir. ${ }^{44}$ Menurut al-Shāfi ‘ ${ }^{1}$ pula, kubur hendaklah ditutup dengan kain bersih sehingga sampai jenazah ke dalam lahadnya. Selain itu, menutup jenazah perempuan semasa memasukkannya ke dalam kubur adalah lebih utama daripada menutup jenazah lelaki. ${ }^{45}$

Amalan meletakkan tanda pada kubur ada dilakukan Rasulullah SAW ketika pengebumian 'Uthmān bin Maẓ'ūn. Baginda meletakkan batu besar pada bahagian kepala kubur jenazah supaya dapat dikebumikan jenazah ahli keluarga yang lain

42 Abū Zakariyya Muḥȳ̄ al-Dīn Yaḥyā bin Sharf al-Nawawī, al-Majmū ‘ Sharḥ alMuhadhdhab (t.tp.: Dār al-Fikr, t.t.), 5: 236.

${ }^{43}$ Muḥammad bin Ismā‘̄il bin Ibrāhīm bin Mughīrah al-Bukhārī, Sāḥ̄ḥ al-Bukhārī, ed. Muḥammad Zuhayr Nāṣir al-Nāșir, Bāb al-Sur'ah bi al-Jināzah, no. Hadith 1315 (t.tp.: Dār Ṭūq al-Najāh, 1422H), r: 86.

44 Aḥmad bin Muḥammad bin 'Al̄̄ bin Hajar al-Ḥaitamī, Tuhfah al-Muḥtāj fì Sharh al-Minhāj (Mesir: al-Maktabah al-Tijāriyyah al-Kubrā, 1983), 3: 197.

45 Muḥammad bin Idrīs bin al- 'Abbās bin 'Uthmān bin Shāfi' bin 'Abd al-Muțalib bin 'Abd Manāf al-Muțalibī al-Qurashī al-Makkī, al-Umm (Beirut: Dār alMa'rifah, 1990), 1: 315. 
berdekatannya di kemudian hari. ${ }^{46}$ Oleh kerana itu, kebanyakan ulama mengharuskan meletakkan tanda pada kubur, namun ada juga yang berpandangan hanya boleh ditanda dengan batu besar sahaja. Dari sudut pengamalan masyarakat setempat pula, responden meletakkan kedua-dua batu nisan dan membina belindan di atas kubur sebagai tanda pada kubur. Perbuatan meletakkan belindan di atas kubur kelihatan bercanggah dengan pandangan alShāfi'ī supaya kubur mesti diratakan, tidak boleh dibangunkan dan tidak boleh dibina batu kapur. ${ }^{47}$ Al-Shāfi ‘'̄ menyukai sekiranya kubur tidak ditambah selain daripada galiannya sendiri dan ditinggikan sekadar sejengkal ${ }^{48}$ bagi membolehkannya dikenali sebagai kubur dan dipohonkan rahmat Allah untuknya. ${ }^{49}$

Adat warisan seterusnya yang diamalkan adalah mengadakan kenduri arwah dan menjemput orang ramai menghadirinya. Dalam sebuah hadith dinyatakan, amalan berkumpul di rumah keluarga si mati dan memakan makanan yang disediakan oleh keluarga si mati adalah sebahagian daripada ratapan. ${ }^{50}$ Sebaliknya, Rasulullah SAW menyuruh jiran tetangga yang tinggal berhampiran dengan keluarga si mati menyediakan makanan buat mereka yang ditimpa musibah kehilangan orang tersayang. ${ }^{51}$ Perbuatan menyediakan makanan ini secara tidak langsung dapat meringankan beban mereka yang sedang berdukacita. Al-Shāfi'ī menegaskan beliau menyukai jika jiran si mati atau orang yang mempunyai pertalian dengannya memberi makan kepada ahli keluarga si mati pada siang hari dan malamnya. ${ }^{52}$ Menurut al-Shāfí' $\overline{1}$ lagi, tiada sandaran yang boleh dipegang sekiranya ahli keluarga si mati yang menyediakan

46 Shams al-Dīn Muhammad bin Aḥmad al-Khațīb al-Sharbīn̄̄, al-Iqnā' fì Hall Alfāz Abū Shujā' (Beirut: Dār al-Fikr, t.t.), 1: 208.

47 Aḥmad bin al-Ḥusayn bin Ạ̣mad al-Aṣfahān̄̄, Matan Abū Shujā' al-Musammāa al-Ghāyah wa al-Taqrīb (t.tp: 'Alim al-Kutub, t.t.), 16.

48 Al-Shāfie, al-Umm, 1:316.

49 Teungku Muhammad Hasbi Ash Shiddieqy, Koleksi Hadith-Hadith Hukum 6 (Jakarta: PT Pustaka Rizki Putra, 2001), 243.

50 Hadith riwayat Ibn Mājah, Bāb Mā Jāa fĩ al-Nahy 'an al-Ijtimā' Ilā Ahl alMayyit wa Șan'ah al-Ṭa'ām, no. Hadith 1612. Lihat Muḥammad bin Yāzid alRābi' bin Mājah al-Qazwīnī, Sunan Ibn Mājah, ed. Muhammad Fu'ād 'Abd alBāqī (t.tp.: Dār al-Iḥyā' al-Kutub al-'Arabiyah, t.t.), 1: 514. Hadith ini adalah sahih.

51 Hadith riwayat Ibn Mājah, Bāb Mā Jāa fī al-Ṭa‘ām Yub‘ath Ilā Ahl al-Mayyit, no. Hadith 16. 1: 514. Hadith ini dinilai sebagai hasan.

52 Al-Shāfi‘‘̄, Al-Umm, 1:317. 
makanan malah ia merupakan rekaan yang tidak disunatkan. ${ }^{53}$ Selain itu, al-Shāfi'ī turut membenci mu'tam iaitu perhimpunan walaupun tanpa tangisan. Ini kerana perbuatan itu akan memperbaharui dukacita dan membebankan tanggungan. ${ }^{54}$

\section{Perincian Berkaitan Amalan Pengurusan Jenazah}

Majoriti imam mazhab bersepakat sekiranya sesuatu hadith itu sahih, maka ia merupakan mazhab mereka walaupun tidak dinyatakan dengan jelas. Al-Nawāwī mencatatkan kata-kata alShāfi'î bahawa tiada percanggahan bagi hadith sahih dan hadith tersebut dikira sebagai mazhabnya malah pengikut mazhabnya diminta supaya meninggalkan pandangannya yang bercanggah dengan hadith sahih. ${ }^{55}$

Hakikat ini membuktikan al-Shāfi'ī sangat mengutamakan hadith sahih bahkan berpesan supaya mazhabnya tidak dipertahankan jika bertentangan dengan hadith sahih. Malah, para ulama turut mengamalkan sikap berhati-hati dengan mengutamakan hadith-hadith yang tidak dikritik serta tidak mempunyai maksud yang saling bercanggahan yang tidak membolehkannya ditarjihkan antara satu sama lain. Ini kerana mustahil bagi dua hadith yang bertentangan dianggap benar tanpa ditarjihkan satu sama lain. ${ }^{56}$ Dalam kaedah pengamalan mazhab Shāfi ‘र̄ di Malaysia pula, pandangan daif turut dipertimbangkan selepas pandangan muktamad mazhab Shāfi'ī sebelum berpindah kepada pandanganpandangan lain daripada baki tiga lagi mazhab sunni dengan berasaskan kepada keperluan kemaslahatan awam dan faedah umum. $^{57}$

Dalam kajian ini, sumber amalan masyarakat Islam mengenai pengurusan jenazah dibahagikan kepada hadith sahih iaitu

53 Abū al-Ḥusayn Yahyā bin Abū al-Khayr bin Sālim al-'Imrānī al-Yaman̄̄ alShāfie, al-Bayān fì Madhab al-Imām al-Shāfie, ed. Qāsim Muḥammad al-Nūrī (Jeddah: Dār al-Minhāj, 2000), 3: 126.

54 Al-Shāfi'‘̄, Al-Umm, 1:318.

55 Al-Nawawī, al-Majmū' Sharh al-Muhadhdhab, 6:370.

56 Wan Hassan bin Wan Embong, Aminuddin bin Ruskam, dan Ahmad Kilani bin Mohamed, "Kajian Takhrij Hadis Sahih Riwayat Bukhari dan Muslim dalam Bab Akidah dan Keimanan" (laporan projek, Pusat Pengajian Islam dan Pembangunan Sosial, Universiti Teknologi Malaysia, 2003), 33.

57 Noor Naemah Abd.Rahman, "Amalan Fatwa di Malaysia: Antara Keterikatan Mazhab dan Keperluan Tarjih,” Jurnal Fiqh, no 4 (2007), 86. 
merangkumi hadith sahih dan juga hasan, hadith mardud seperti daif, terlalu daif dan palsu serta amalan daripada adat warisan. Perincian berkaitan amalan pengurusan jenazah yang dikemukakan kepada responden berserta sumber amalan berkaitan dapat dilihat pada Jadual 2.

Jadual 2: Amalan Pengurusan Jenazah

\begin{tabular}{|c|c|c|c|}
\hline No & Perkara & Reaksi & Sumber \\
\hline 1. & $\begin{array}{l}\text { Menggunakan } 3 \text { kain kafan putih } \\
\text { untuk jenazah lelaki dan } 5 \text { untuk } \\
\text { jenazah perempuan }\end{array}$ & Setuju & $\begin{array}{l}\text { Hadith } \\
\text { sahih }\end{array}$ \\
\hline 2. & $\begin{array}{l}\text { Memperbanyakkan ucapan là ilaha } \\
\text { illā Allāh kepada jenazah }\end{array}$ & Setuju & $\begin{array}{c}\text { Hadith } \\
\text { daif }\end{array}$ \\
\hline 3. & $\begin{array}{l}\text { Berdiri di tengah bagi jenazah } \\
\text { lelaki dan di bahagian bahu bagi } \\
\text { jenazah wanita }\end{array}$ & Setuju & $\begin{array}{l}\text { Hadith } \\
\text { sahih }\end{array}$ \\
\hline 4. & $\begin{array}{l}\text { Membaca wirid dan berdoa selepas } \\
\text { solat jenazah }\end{array}$ & Setuju & $\begin{array}{c}\text { Adat } \\
\text { warisan }\end{array}$ \\
\hline 5. & $\begin{array}{l}\text { Menghantar ucapan takziah kepada } \\
\text { keluarga si mati }\end{array}$ & Setuju & $\begin{array}{l}\text { Hadith } \\
\text { sahih }\end{array}$ \\
\hline 6. & 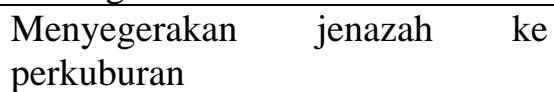 & Setuju & $\begin{array}{l}\text { Hadith } \\
\text { sahih }\end{array}$ \\
\hline 7. & $\begin{array}{l}\text { Mengiringi jenazah sambil } \\
\text { membaca لا إله إلا الله }\end{array}$ & Setuju & $\begin{array}{l}\text { Hadith } \\
\text { palsu }\end{array}$ \\
\hline 8. & $\begin{array}{l}\text { Memayungi jenazah semasa ke } \\
\text { tanah perkuburan }\end{array}$ & Setuju & $\begin{array}{c}\text { Adat } \\
\text { warisan }\end{array}$ \\
\hline 9. & $\begin{array}{l}\text { Jenazah diletakkan ke dalam liang } \\
\text { lahad dengan menghadap kibat }\end{array}$ & Setuju & $\begin{array}{l}\text { Pandangan } \\
\text { Shāfi'iyyah }\end{array}$ \\
\hline 10. & $\begin{array}{l}\text { Melaungkan azan } \\
\text { meletakkan jenazah ke } \\
\text { kubur }\end{array}$ & $\begin{array}{l}\text { Tidak } \\
\text { Pasti }\end{array}$ & $\begin{array}{c}\text { Adat } \\
\text { warisan }\end{array}$ \\
\hline 11. & $\begin{array}{l}\text { Meletakkan pelepah atau menanam } \\
\text { pokok di atas kubur setelah jenazah } \\
\text { dikebumikan }\end{array}$ & Setuju & $\begin{array}{l}\text { Pandangan } \\
\text { Shāfi'iyyah }\end{array}$ \\
\hline 12. & $\begin{array}{l}\text { Meletakkan batu nisan dan } \\
\text { belindan di atas kubur }\end{array}$ & Setuju & $\begin{array}{c}\text { Adat } \\
\text { warisan }\end{array}$ \\
\hline
\end{tabular}




\begin{tabular}{|c|l|c|c|}
\hline 13. & $\begin{array}{l}\text { Membaca talqin kepada jenazah } \\
\text { supaya jenazah yang ditalqinkan } \\
\text { akan terlepas daripada soal jawab } \\
\text { kubur }\end{array}$ & $\begin{array}{c}\text { Tidak } \\
\text { Pasti }\end{array}$ & $\begin{array}{c}\text { Hadith } \\
\text { daif }\end{array}$ \\
\hline 14. & $\begin{array}{l}\text { Bersama majlis bacaan talqin bagi } \\
\text { jenazah selepas jenazah } \\
\text { dikebumikan }\end{array}$ & Setuju & $\begin{array}{c}\text { Hadith } \\
\text { daif }\end{array}$ \\
\hline 15. & $\begin{array}{l}\text { Meletakkan muka di atas kubur dan } \\
\text { menciumnya }\end{array}$ & $\begin{array}{c}\text { Tidak } \\
\text { Setuju }\end{array}$ & $\begin{array}{c}\text { Hadith } \\
\text { daif }\end{array}$ \\
\hline 16. & Mengadakan kenduri arwah & Setuju & $\begin{array}{c}\text { Adat } \\
\text { warisan }\end{array}$ \\
\hline 17. & $\begin{array}{l}\text { Memberi salam dan berdoa kepada } \\
\text { penghuni kubur setiap kali melalui } \\
\text { kawasan perkuburan }\end{array}$ & Setuju & $\begin{array}{c}\text { Hadith } \\
\text { sahih }\end{array}$ \\
\hline 18. & $\begin{array}{l}\text { Duduk di atas kubur dan bersandar } \\
\text { padanya semasa menziarahi kubur }\end{array}$ & $\begin{array}{c}\text { Tidak } \\
\text { Setuju }\end{array}$ & $\begin{array}{c}\text { Adat } \\
\text { warisan }\end{array}$ \\
\hline 19. & $\begin{array}{l}\text { Membaca Surah Yasin di kubur ibu } \\
\text { bapa pada hari Jumaat }\end{array}$ & Setuju & $\begin{array}{c}\text { Hadith } \\
\text { palsu }\end{array}$ \\
\hline 20. & Menziarahi kubur pada hari raya & Setuju & $\begin{array}{c}\text { Hadith } \\
\text { terlalu daif }\end{array}$ \\
\hline
\end{tabular}

Terdapat empat amalan yang bersumberkan hadith daif dan adat warisan yang dikemukakan kepada responden tetapi mendapat reaksi tidak pasti dan tidak bersetuju daripada responden. Amalanamalan tersebut adalah melaungkan azan setelah meletakkan jenazah ke dalam kubur, membaca talqin kepada jenazah supaya jenazah yang ditalqinkan akan terlepas daripada soal jawab kubur, meletakkan muka di atas kubur dan menciumnya serta duduk di atas kubur dan bersandar padanya semasa menziarahi kubur. Hasil pemerhatian terhadap amalan-amalan tersebut di kawasan kajian menunjukkan responden tidak melakukannya walaupun tidak pasti dengan amalan tersebut. Oleh itu, dapatlah dirumuskan bahawa tindakan meninggalkan amalan-amalan tersebut adalah lebih mendekati sunnah memandangkan Rasulullah SAW juga tidak melakukannya.

Namun begitu, harus diambil perhatian bahawa menentukan balasan dosa atau pahala secara tuntas kepada individu lain sebagai implikasi terhadap pengamalan amalan-amalan daripada sumber yang tidak sahih bukanlah tugas mana-mana individu. Bahkan sudah menjadi tanggungjawab seorang muslim meneladani ajaran 
Rasulullah SAW malah sangat digalakkan agar berpegang kepada sunnah sebagai panduan hidup lebih-lebih lagi dalam aspek ibadah seperti pengurusan jenazah.

\section{Penutup}

Kajian ini secara keseluruhannya menjelaskan empat sumber yang dirujuk oleh masyarakat Islam dalam melaksanakan pengurusan jenazah iaitu hadith sahih, pendapat ulama Shāfi'iyyah, hadith mardud yang terdiri daripada hadith daif, terlalu daif dan palsu dan yang keempat adat warisan. Hasil kajian menunjukkan sumber utama amalan masyarakat adalah daripada hadith sahih dan pandangan Shāfi'iyyah. Selain itu, kajian ini juga secara tidak langsung membuktikan masyarakat Islam di Mukim Kutan, Tumpat Kelantan mempunyai kecenderungan menerima amalan-amalan baharu yang kelihatan positif terutama amalan yang disulami dengan ayat al-Quran dan zikir-zikir tertentu. Pegangan terhadap amalan warisan juga menzahirkan kesungguhan masyarakat dalam mengekalkan keaslian amalan yang dilakukan. Namun begitu, masyarakat setempat juga sangat prihatin terhadap sumber amalan ibadah yang dilakukan malah bersedia memperbaiki amalan yang dikenalpasti tidak sahih serta bersedia meninggalkan amalan yang bercanggah dengan sumber Islam yang sebenar. Sikap ini secara tidak langsung membuktikan kewujudan konsep kendiri positif dalam diri dengan ciri personaliti yang baik iaitu optimis, tenang dan lebih terbuka dalam menerima pendapat mahupun kritikan orang lain. ${ }^{58}$ Justeru, kajian ini diharap dapat memberi kesedaran akan salah faham terhadap hadith daif dan palsu serta mendorong masyarakat supaya mengambil berat terhadap bahaya amalan ibadah yang bercanggah dengan hadith sahih khususnya dalam pengurusan jenazah. Oleh itu, masyarakat diharap dapat memupuk kesedaran dan menanam kebiasaan dalam diri untuk sentiasa menyemak kesahihan setiap maklumat yang diterima dalam kehidupan seharian. Amalan yang bersumberkan daripada adat warisan juga hendaklah diteliti semula bagi memastikan ia tidak bercanggah dengan hadith sahih. Kajian ini juga diharapkan dapat membantu masyarakat dalam memahami kepentingan pengurusan

58 Siti Jamiaah Abdul Jalil, Yusmini Md Yusoff dan Rozmi Ismail, "Pembinaan Konsep Kendiri dari Perspektif Barat dan Islam," Jurnal Usuluddin, no. 45 (1) 2017, 3. 
jenazah yang sebenar menurut Islam serta berani untuk menolak amalan tradisi yang bercanggah dengan budaya Islam.

\section{Rujukan}

Aḥmad bin al-Ḥusayn bin Aḥmad al-Aṣfahān̄i. Matan Abū Shujā ‘ al-Musammā al-Ghāyah wa al-Taqrīb. T.tp: 'Alim al-Kutub, t.t. Ahmad Mohamed Ibrahim dan Ahilemah Joned. Sistem Undangundang di Malaysia. Kuala Lumpur: Dewan Bahasa dan Pustaka. Ahmad Mohd Salleh. Pendidikan Islam: Falsafah, Sejarah dan Kaedah Pengajaran Pembelajaran. Selangor: Penerbit Fajar Bakti, 2004,

Al-'Asqalānī. Aḥmad bin 'Alī bin Muḥammad bin Aḥmad bin Hajar. Fatḥ al-Bārī Sharh Șaḥ̄h al-Bukhārī, ed. Muḥammad Fu'ād 'Abd al-Bāqī et al. Beirut: Dār al-Ma'rifah, 1957.

Al-Anșārī. Zakariyyā. Fath al-Wahhāb Sharh Minhaj al-Ṭullāb. Beirut: Dār al-Fikr, t.t.

Al-Bukhārī. Muhammad bin Ismā'̄il bin Ibrāhīm bin Mughīrah. Sāhīh al-Bukhārī, ed. Muhammad Zuhayr Nāṣir al-Nāṣir. T.tp.: Dār TTūq al-Najāh, 2000.

Al-Haitamī, Aḥmad bin Muḥammad bin 'Alī bin Ḥajar. Tuhfah alMuhtāj fi Sharh al-Minhājo. Mesir: al-Maktabah al-Tijāriyyah alKubrā, 1983.

Al-Hanz̧alī. Abū 'Abd al-Raḥman'Abd Allah bin al-Mubārak bin Wāọiḥ. Al-Zuhd, ed. Habīb al-Raḥman al-A'ẓamī. Beirut: Dār alKutub al-'Ilmiyyah, t.t.

Al-Lujnah al-Dāimah li al-Buhūth al-'Ilmiyyah wa al-Iftā'. Fatāwā al-Lujnah al-Dāimah-al-Majmū' 'ah al-Ūlā.

Al-Nawāwī Abū Zakariyya Muḥȳ̄ al-Dīn Yahyā bin Sharf. Ruḍh al-Tāilibìn wa 'Umdah al-Muftiyyīn. Beirut: al-Maktab al-Islāmī. Al-Nawāwī, Abū Zakariyyā Muḥȳ̄ al-Dīn Yahyā bin Sharf. AlAdhkār, ed. 'Abd al-Qādir al-Arnā'ūt. Beirut: Dār al-Fikr, 1994.

Al-Nawāwī, Abū Zakariyyā Muhyȳi al-Dīn Yahyā bin Sharf. AlMajmū' Sharh al-Muhadhdhab. T.tp.: Dār al-Fikr, t.t.

Al-Shāfí' '̄, Abū 'Abd Allāh Muḥammad bin Idrīs bin al-'Abbās bin 'Uthmān bin Shāfi' bin 'Abd al-Muțalib bin 'Abd Manāf alMuțalibī al-Qurashī al-Makkī. Al-Umm. Beirut: Dār al-Ma'rifah, 1990.

Al-Sharbīnī. Shams al-Dīn Muḥammad bin Aḥmad al-Khațīb. AlIqnā' fì Hall Alfāz Abū Shujā' '. Beirut: Dār al-Fikr, t.t. 
Al-Sharbīn̄ī. Shams al-Dīn Muhammad bin Ahmad al-Khațīb. AlMughnī al-Muhtāj Ilā Ma 'rifah Ma 'ānī al-Fāz al-Minhāj. T.tp: Dār al-Kutub al-'Ilmiyyah, 1994.

Al-Sijistāni, Sulaymān bin al-Ash'ath bin Ishāq bin Bashīr bin Shidād bin 'Amr al-Azdi. Sunan Abū Dāud, ed. Muhammad Muhyī al-Dīn 'Abd al-Ḥamīd. Beirut: al-Maktabah al-'Așriyyah, t.t.

Al-Wansharīsī. Abū al-'Abbās Aḥmad bin Yahyāà. Al-Mi' yār alMa 'rab wa al-Jāmi'al-Maghrab 'an Fatāwā Ahl Ifrīqiyyah wa al-Andalus wa al-Maghrab, ed. Muhammad Hujjājī. Beirut: Dār Maghrab al-Islāmī, 1989.

Al-Wansharīsī. Abū al-'Abbās Aḥmad bin Yaḥyā. Al-Mi 'yār alMu 'rab wa al-Jāmi' al-Maghrib 'an Fatāwā Ahl Ifrīqiyyah wa al-Andalus wa al-Maghrib, ed. Muhammad Hujjajī et al. Beirut: Dār al-Gharb al-Islāmī, 1988.

Al-Wansharīsī. Aḥmad bin Yaḥyā. Wafayāt al-Wansharīs̄i, ed. Muḥammad Hujjajī. Beirut: Dār al-Gharb al-Islāmīî, 1995.

Azyumardi Azra. Renaisans Islam Asia Tenggara: Sejarah Wacana dan Kekuasaan. Bandung: PT Remaja Rosdakarya.

Bin Sālim, Abū al-Husayn Yaḥyā bin Abū al-Khayr. Al-Bayān fì Madhab al-Imām al-Shāfi '̄o ed. Qāsim Muhammad al-Nūrī. Jeddah: Dār al-Minhāj, 2000.

Hamidah Abdul Wahab et. al, "Eufemisme Pengurusan Jenazah Masyarakat Melayu Sarawak: Analisis Semantik Kognitif," Jurnal Bahasa 16, no. 1 (2016).

Ibn al-Khaț̣āb Abū Sulaymān bin Muḥammad bin Ibrāhīm. Ma 'ālim al-Sunan. Halb: al-Mațba'ah al-'Ilmiyyah, 1932.

Ibn Kathīr, Ismā'īl bin 'Umar. Tafsīr al-Quran al-'Ażìm, ed. Sāmī bin Muḥammad Salāmah. T.tp: Dār Ṭayyibah, 1999.

Ibn Majah al-Qazwīn̄̄ Abū 'Abd Allah Muhammad bin Yazid alRabi'. Sunan Ibn Mājah, ed. Muḥammad Fu'ād 'Abd al-Bāqī. t.tp.: Dār al-Ihyyā' al-Kutub al-'Arabiyah, t.t.

Idris Awang, Tengku Sarina Aini Tengku Kassim. "Pembudayaan Mazhab Syafi'i dalam Masyarakat Islam di Malaysia," Jurnal Fiqh, no. 4 (2007).

Jabatan Perancangan Bandar dan Desa Negeri Kelantan. "Rancangan Tempatan Jajahan Tumpat, Jabatan Perancangan Bandar dan Desa Negeri Kelantan." Perpustakaan Negara 
Malaysia Data Pengkatalogan - dalam - Penerbitan Rancangan Tempatan Jajahan Tumpat, 2011.

Mohammad Redzuan Othman. "Masjid al-Haram dan Peranannya dalam Perkembangan Awal Pendidikan dan Intelektualisme Masyarakat Melayu," Jurnal Usuluddin, no. 13 (2001).

Muhammad Ikhlas Rosele dan Abdul Karim Ali. "Konsep Kearifan Tempatan Menurut Perspektif Hukum Islam," Jurnal Fiqh, no 16 (2019).

Najmiah binti Omar dan Zulkifli@Md. Yaakub bin Mohd Yusuf. "Perkembangan Pengajian Tarannum Al-Quran di Terengganu Pada Zaman Pra-Merdeka Sehingga Tahun 2014," Jurnal Islam dan Masyarakat Kontemporari, no. 13 (2016).

Noor Naemah Abd.Rahman. "Amalan Fatwa di Malaysia: Antara Keterikatan Mazhab dan Keperluan Tarjih," Jurnal Fiqh, no 4 (2007).

Rahimin Affandi Abdul Rahim et.al, "Islam dan Kearifan Tempatan di Alam Melayu: Analisis Kritikal," Jurnal Jati, no. 18 (2013).

Siti Jamiaah Abdul Jalil, Yusmini Md Yusoff dan Rozmi Ismail. "Pembinaan Konsep Kendiri dari Perspektif Barat dan Islam," Jurnal Usuluddin, no. 45 (2017).

Teungku Muhammad Hasbi Ash Shiddieqy. Koleksi Hadith-Hadith Hukum 6. Jakarta: PT Pustaka Rizki Putra, 2001.

Yulyenita. "Tradisi Penyelenggaraan Jenazah di Pulau Tengah Kecamatan Keliling Danau Kabupaten Ditinjau dari Hukum Islam." Disertasi, Jabatan Fiqh \& Usul, Akademi Pengajian Islam, Universiti Malaya, 2009.

Zulkifli Mohamad al-Bakri. Fiqh Jenazah: Panduan Pengurusan, Hukum \& Fatwa. Negeri Sembilan: Pustaka Cahaya Kasturi Sdn Bhd, 2017. 